\title{
ARCHEOLOGIE NEJSTARŠÍHO HORIZONTU MĚSTA POČÁTKY (OKRES PELHŘIMOV)
}

\author{
KATEŘINA TĚSNOHLÍDKOVÁ - JAKUB TĚSNOHLÍDEK - PETR DUFFEK
}

\begin{abstract}
Abstrakt: Článek se zabývá archeologickými situacemi a nálezy, které je možné datovat do druhé poloviny 13. až první poloviny 14. století a lze je spojit s nejstarši historii mésta Počátky. V tomto obdobi mélo město protáhlé vřetenovité centrum, které bylo nejpozději na počátku 16. století rozděleno kamennou hradbou na menši náměsti kolem kostela sv. Jana Křtitele a nechráněné jižní předměstí. Obě plochy byly postupně archeologicky zkoumány v letech 2010-2016. Hlavni část článku představuje vyhodnoceni keramického souboru ze zahloubeného suterénu na Palackého náměstí. Dále jsou zde publikovány drobné soubory keramiky z výzkumů na Mariánském náméstí, ze soukromé sbirky p. Matouška a ze sbirek muzea v Počátkách.
\end{abstract}

Klíčová slova: 13. stoleti - keramika - zahloubený suterén-Počátky-náměstí.

\section{Archaeology of the earliest horizon of the Počátky town (Pelhřimov district)}

Abstract: This article discusses the archaeological contexts and finds that are dated to the second half of the 13th century or to the first half of the 14th century, and are associated with the earliest history of the town of Poćátky. In this period the town had an elongated, spindle-shaped centre which was, in the early 16 th century at the latest, divided by a stone wall into a small square around the Church of St. John the Baptist and an unprotected southern suburb. Both these areas were gradually archeologically researched in 2010-2016. The main part of the article brings an assessment of a pottery series from a sunken cellar in Palackého náméstí Square. In addition, the paper also presents small ceramic series from excavations in Mariánské náměstí Square, from a private collection of Mr. Matoušek and from the collections of the Počátky museum.

Key words: 13th century - pottery - sunken cellar-Počátky-square.

\section{1 Úvod}

V roce 2015 provedlo jihlavské pracoviště společnosti Archaia Brno, o.p.s., plošný záchranný výzkum při rekonstrukci Palackého náměstí v Počátkách (Duffek et al. 2017). Akce volně navazovala na předešlý výzkum uskutečněný při stavbě odpadních a vodovodních sítí na počáteckém náměstí (Černoš 2012). Výzkum odhalil situace související se založením města $\mathrm{v}$ druhé polovině 13 . století a s jeho provozem ve vrcholném a pozdním středověku, většina archeologických prací se však týkala struktur 16.-19. století. Získané poznatky byly doplněny v roce 2016 výzkumem Mariánského náměstí, nacházejícího se jižně od městského centra (Duffek-Těsnohlídek 2017). Zájmová lokalita se nachází na jižním okraji okresu Pelhřrimov, přibližně $30 \mathrm{~km}$ jihozápadním směrem od města Jihlavy, v nadmořské výšce $620 \mathrm{~m} \mathrm{n}$. $\mathrm{m}$. (obr. 1).

Studie se souhrnně zaměřuje na archeologické situace a nálezy z období počátků města, tedy horizont 13. a počátku 14. století a navazuje na článek z roku 2017 „Výsledky archeologického výzkumu Palackého náměstí v Počátkách (okres Pelhřimov)“, v němž je podrobně popsána historie lokality i archeologické situace. Pokud není v textu uvedena citace, vycházejí autoři z tohoto zdroje, případně z nálezové zprávy (Těsnohlídek et al. 2017; Duffek et al. 2017).

Hlavní pozornost je věnována vyhodnocení keramických nálezů ze zahloubeného suterénu č. 0518 na Palackého náměstí. Doplňující jsou nálezové situace z Mariánského náměstí. V rámci hmotné kultury je vyhodnocena také keramika datovatelná do daného období získaná amatérskými průzkumy či náhodnými nálezy (sbírka p. Matouška, depozitář Muzea Počátky). 


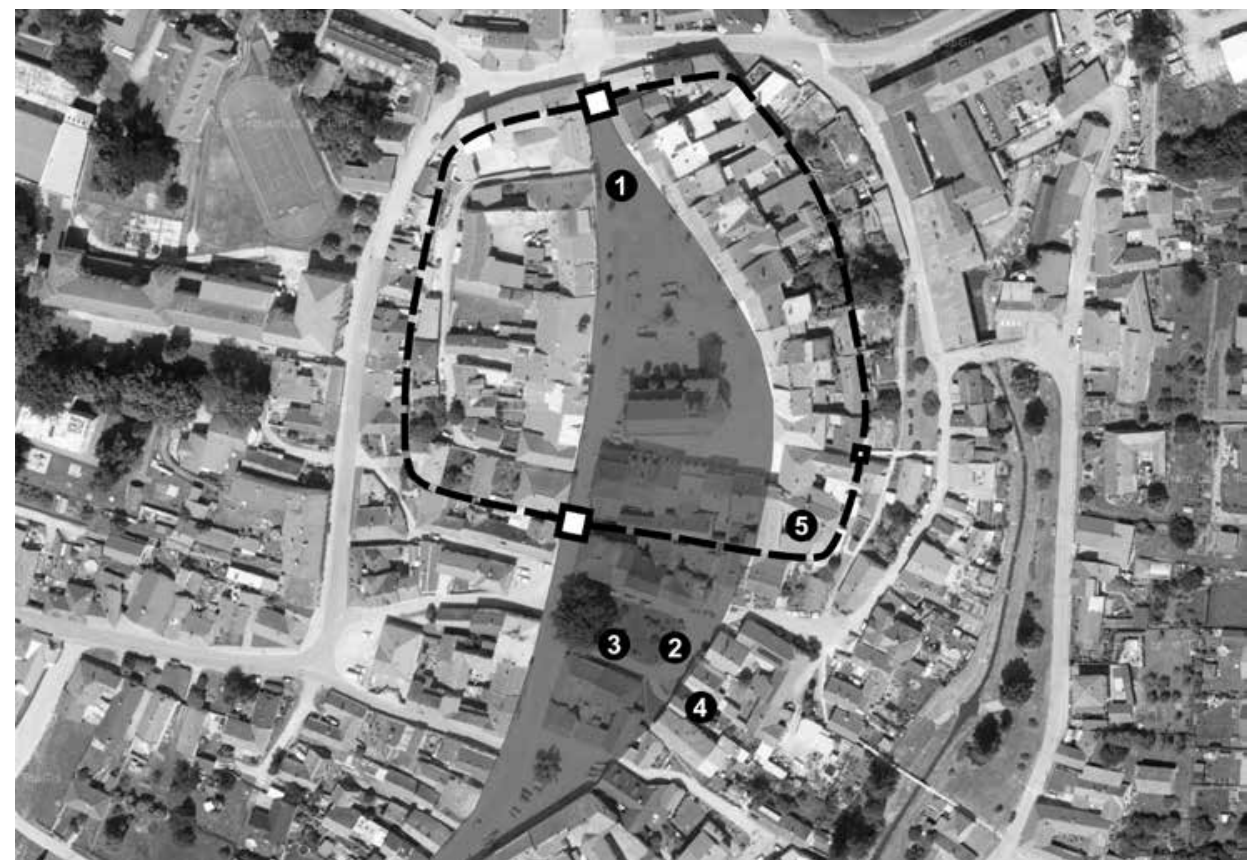

Obr. 1. Centrum města Počátek s vyznačením staršího vřetenovitého náměstí (šedá), hradebního pásu (přerušovaná čára) a městských bran (bílá). Na severu se nachází Palackého náměstí, v jižní části Mariánské náměstí. Čísla označují místa nálezů: 1 - suterén č. 0518; 2 - obj. 1539; 3 - obj. 1540; 4 - čp. 626, p. Matoušek; 5 - čp. 2, děkanství. Autor P. Duffek.

Abb. 1. Zentrum der Stadt Počátky mit eingezeichnetem älteren, spindelförmigem Marktplatz (grau), Stadtmauergürtel (gestrichelte Linie) und Stadttoren (weiß). Im Norden befindet sich der Palacký-Platz, im Südteil der Marienplatz. Die Ziffern bezeichnen die Fundstellen: 1 - Souterrain Nr. 0518; 2 - Obj. 1539; 3 - Obj. 1540; 4 - Konskriptionsnr. 626, Herr Matoušek; 5 - Konskriptionsnr. 2, Dekanat. Autor P. Duffek.

\section{Počátky ve vrcholném středověku}

\section{Stručná historie města ve 13. a 14. století}

Počátky vyrostly na staré cestě spojující Jihlavu s Jindřichovým Hradcem. Území na severozápadě směrem od Černovic přes Kamenici nad Lipou k Horní Cerekvi kolonizoval rod Benešoviců a okolí vrchu Javořice na jihovýchodě s hradem Šternberk rod Šternberků. Ve 13. století se Počátecko nacházelo mezi biskupským Pelhřimovskem a Jindřichohradeckem pánů z Hradce. Formulář Tobiáše z Bechyně udává, že v období sporů mezi Vítkovci a pražským biskupem se oblast stala obětí plenění. List datovaný mezi roky 1285-1290, který je zároveň první dochovanou zmínkou o Počátkách, však neř́íá, o jaký typ sídla se tehdy jednalo. V roce 1303 bylo na počáteckém statku (bonum) zapsáno věno Berty, druhé manželky Vítka ze Švábenic. V letech 1356-1358 se na Počátkách uvádí Štěpán z Březnice, který vlastnil větší panství na moravském území s městem Třešt' a hrady Šternberk a Janštejn. Poté držel Počátky Jan z Hardeka, purkrabí magdeburský a pán na Kozí, který je 8. září 1389 prodal Jindřichovi III. z Hradce i se všemi užitky za 687 kop grošů pražských (Těsnohlídek et al. 2017, 670).

\section{Dispozice náměstí a městské opevnění}

Počátky vyrostly postupným rozšířením původní osady, která se rozkládala na pravobřežní vyvýšené poloze nad Počáteckým potokem. Půdorys městečka měl tranzitní charakter. Podél 
dálkové trasy se rozvinulo přibližně $280 \mathrm{~m}$ dlouhé a $70 \mathrm{~m}$ široké vřetenovité náměstí (Kovár̆ 2012, 39).

Nejpozději na začátku 15. století již bylo město opevněno, ovšem během obléhání husitskými vojsky v letech 1423 a 1425 došlo k takovým škodám, že opevnění musely nahradit provizorní ploty. Skutečné kamenné hradby (deklarované privilegiem Jindřicha IV.) vznikly až někdy před rokem 1504 a významně zasáhly do urbanistického plánu města. Nová vnitřní hradba přet’ala dosavadní náměstí, které se nyní zmenšilo na trojúhelník kolem farního kostela, zatímco oddělená jižní část získala charakter pouhého nechráněného předměstí. Město bylo přístupné dvěma branami (na severu Horní a na jihu Dolní), komunikační schéma doplňovala malá branka vedoucí východním směrem k vodoteči a soustavě rybníků (Kuča 2002, 271; Těsnohlídek et al. 2017, 260; obr. 1).

Archeologické výzkumy obou náměstí podporují předpoklad o jejich rozdělení nejpozději počátkem 16. století. Dokumentované situace na Palackého (suterén č. 0518) i Mariánském náměstí (S01, obj. 1539, obj. 1540) obsahovaly identický keramický materiál konce 13. a počátku 14. století. Je pravděpodobné, že starší provizorní opevnění obíhalo celé vřetenovité centrum města a teprve výstavba kamenných hradeb zapřičinila z hlediska nákladů zmenšení opevněné plochy.

Na základě dosavadního poznání nelze určit, jak městské opevnění přesně vypadalo. Víme, že centrum obíhala kamenná hradba, do které byly na severu a jihu vsazeny věžovité brány. Je otázkou, zda byla hradba vybavena také některými prvky aktivní obrany. Současný vzhled staveb a parcel, kudy opevnění probíhalo a kde předpokládáme zakomponování tělesa hradby, nenapovídá existenci bašt, ani věží. Situaci by v budoucnu mohl osvětlit archeologický výzkum, prrípadně stavebně historický průzkum některého $\mathrm{z}$ měšt’anských domů stojících v místě opevnění.

\section{Vrcholně středověké situace na Palackého náměstí - zahloubený suterén č. 0518}

Záchranný archeologický výzkum při rekonstrukci Palackého náměstí v Počátkách přinesl široké spektrum informací o vývoji a historii města ve středověku a novověku. K nejstarším zachyceným situacím náleží kromě drobného výzkumu Horní brány v roce 2011 (Černoš 2012, 12-15) především zahloubený suterén dřevohliněné nadzemní stavby, datované do druhé poloviny 13. století, zachycený v roce 2015 v severní části náměstí před domem čp. 6 . Suterén č. 0518 představuje vůbec nejstarší zachycenou archeologickou situaci ve městě Počátky. Podobné stavby byly v posledních desetiletích zkoumány i v jádrech měst Pelhřimov, Humpolec nebo Jihlava, jsou typické pro druhou polovinu 13. století a již koncem 13. a v průběhu první poloviny 14. století mizí. Suterén č. 0518 přinesl zásadní informace k podobě nezděné architektury, keramické produkce a využití krajiny v okolí města Počátky na přelomu 13. a 14. století (Těsnohlídek et al. 2017, 672).

Kvadratický obdélný výkop o rozměrech 5,2 m (sever-jih), 3,6 m (východ-západ) a hloubce 1,12 až $0,54 \mathrm{~m}$ byl zahlouben v pevném rulovém podloží. Vstupní šíje nebyla zachycena, ale je možné, že se nacházela $v$ části zničené starším výkopem pro kanalizaci. Stěny výkopu byly př́imé, s ostrým přechodem do dna, na stěnách i podlaze byly patrné traseologické stopy nástrojů, jimiž byl výkop vyhlouben. Na dně se nacházel vytesaný základový žlábek se zbytky trámového věnce (obr. 2, 3).

Odebrané vzorky dřeva byly určeny jako jedle. Na dně objektu ležel šedý $0,02-0,06 \mathrm{~m}$ mocný podlahový nášlap s malými zlomky uhlíků, mazanice a velmi malými zlomky kamenů. Ve středu podlahy suterénu byl tento podlahový nášlap tvořen až čtyřmi vrstvami stejného charakteru. Zásyp suterénu tvořily $\mathrm{v}$ dolní části homogenní hlinitopísčité vrstvy s menším podílem uhlíků a kamenů. Ve střední části zásypu se střídaly hlinité vrstvy s vrstvami z velké části tvořené uhlíky a písčitou hlínou. Situaci uzavíral zásyp velkých kamenů $(0,1-0,66 \mathrm{~m})$ a písčité hlíny (Těsnohlídek et al. 2017, 672-673). 


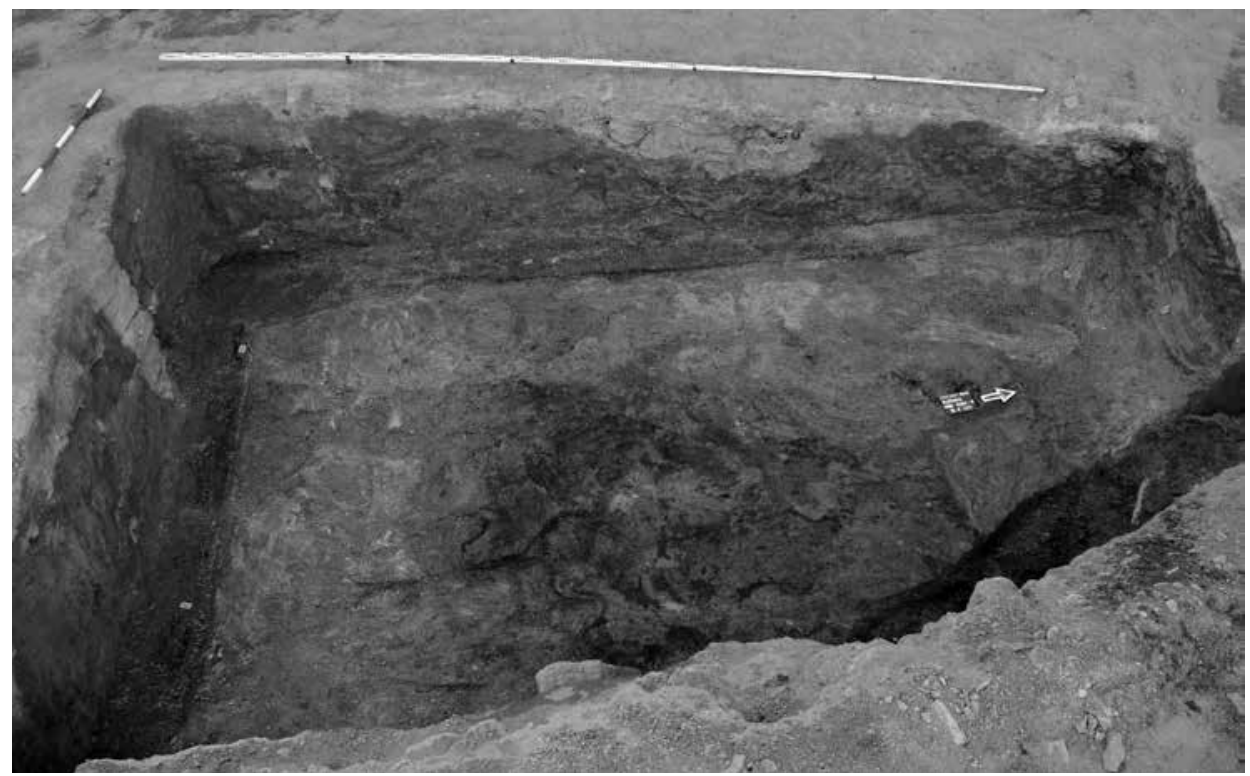

Obr. 2. Snímek zahloubeného suterénu č. 0518. Podél stěn jsou patrné žlábky se zbytky základového trámového věnce, situace je začištěna na úroveň nášlapových vrstev. Archiv Archaia Brno, o.p.s..

Abb. 2. Aufnahme des eingetieften Souterrains Nr. 0518. Entlang den Wänden sind Rinnen mit den Resten des Fundamentbalkenkranzes erkennbar, die Situation wurde bis zum Niveau der Gehschichten gereinigt. Archiv Archaia Brno, o.p.s..

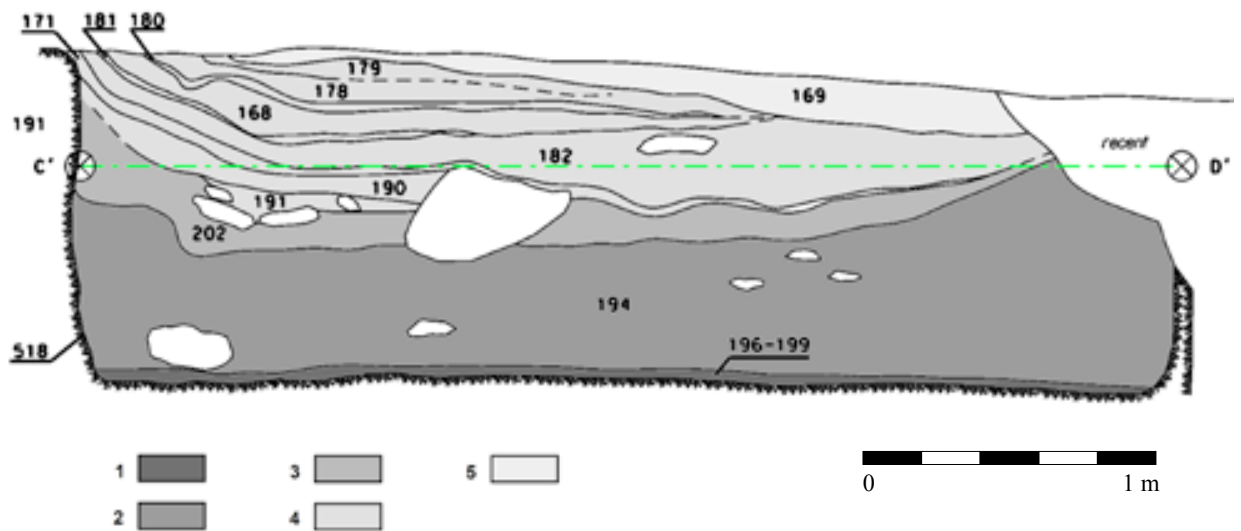

Obr. 3. Jižní řez suterénem č. 0518 (Palackého náměstí), pro účely analýzy keramického souboru byla výplň rozdělena do skupin 1-5. Digitalizace M. Daňa, upravil J. Těsnohlídek.

Abb. 3. Südlicher Schnitt durch das Souterrain Nr. 0518 (Palacký-Platz), für die Analyse des Keramikkomplexes wurde die Verfüllung in die Gruppen 1-5 untergliedert. Digitalisierung M. Daňa, bearbeitet von J. Těsnohlídek.

Svrchní a střední část zásypu obsahovaly z nekeramických nálezů především kovářské strusky, hřebíky a dvě ramena podkov. Na jejich bázi se nacházela písčitá vrstva obsahující fragment železného nože a bronzový plíšek. Střední zásyp obsahoval několik úlomků plechu $\mathrm{z}$ barevného kovu a množství hřebů. Podlahové a komunikační vrstvy suterénu č. 0518 neobsahovaly žádné kovové nálezy (Těsnohlídek et al. 2017, 672). 
4 Keramický soubor ze suterénu č. 0518 z Počátek: technologie, morfologie a prŕíspěvek k poznání stratigrafie objektu

Keramika ve výplni suterénu č. 0518 svým charakterem odpovídá období druhé poloviny 13. až začátku 14. století, podrobnější datování není možné vzhledem k nedostatečnosti zpracovaných kvalitních keramických souborů v regionu a neumožňuje jej ani stratigrafie v objektu. V objektu bylo celkem obsaženo 1788 fragmentů keramiky.

Pro účely vyhodnocení keramického souboru byly vrstvy sloučeny do pěti skupin (tab. 1, obr. 3). O charakteru vrstev svědčí fragmentarizace keramiky v jednotlivých úrovních objektu. Ta je nejvyšší u keramiky ze spodní skupiny vrstev, které lze považovat za nášlapové. V ostatních vrstvách je fragmentarizace keramiky podobná a směrem $\mathrm{k}$ vrchní části objektu se mírně snižuje. To odpovídá postupnému zaplnění objektu.

Slepitelnost keramiky se pohybovala okolo $9 \%$. Lze počítat se ztrátou části fragmentů při výzkumu (charakter záchranného výzkumu neumožňuje získání všech fragmentů z objektu) a zároveň $\mathrm{s}$ nedohledáním některých slepitelných fragmentů (především v případě výdutí). Do objektu se nedostávaly celé nádoby, ale až jejich fragmenty spolu s hlínou, šlo tedy o minimálně sekundárně přemístěné vrstvy, kterými byl objekt po svém zániku postupně zaplněn (s výjimkou tenkých nášlapových vrstev 1. skupiny).

\begin{tabular}{|l|c|c|c|c|c|c|c|c|c|c|c|c|c|c|}
\hline Interpretace vrstev & $\begin{array}{c}\text { Skupina } \\
\text { vrstev / KT }\end{array}$ & 1 & 2 & 3 & 4 & 5 & 6 & 7 & 8 & 9 & 10 & 11 & 12 & $\begin{array}{c}\text { Celkem } \\
\text { fragmentů }\end{array}$ \\
\hline $\begin{array}{l}\text { Zásypové } \\
\text { (s velkými kameny) }\end{array}$ & 5 & 43 & 7 & 29 & 16 & 42 & 2 & 31 & 0 & 12 & 90 & 0 & 0 & 272 \\
\hline Zásypové & 4 & 74 & 0 & 126 & 19 & 36 & 3 & 30 & 0 & 1 & 15 & 0 & 0 & 304 \\
\hline Zásypové & 3 & 43 & 21 & 123 & 27 & 59 & 0 & 75 & 0 & 1 & 80 & 0 & 6 & 435 \\
\hline $\begin{array}{l}\text { Zásypové } \\
\text { (nad nášlapovými) }\end{array}$ & 2 & 76 & 41 & 105 & 30 & 81 & 0 & 168 & 1 & 0 & 88 & 0 & 3 & 593 \\
\hline Nášlapové & 1 & 38 & 11 & 66 & 11 & 17 & 0 & 3 & 0 & 1 & 36 & 1 & 0 & 184 \\
\hline
\end{tabular}

Tab. 1. Zastoupení KT 1-12 ve skupinách vrstev 1-5 včetně interpretace vrstev - podle počtu fragmentů.

Tab. 1. Vorkommen der Keramikklassen 1-12 in den Gruppen der Schichten 1-5 einschließlich Interpretation der Schichten - gemäß der Fragmentanzahl.

Základem pro vyhodnocení keramiky jsou keramické tř́ídy (dále jen KT). Ty jsou definovány na základě vlastností vycházejících z operačního řetězce keramiky. Jde o vlastnosti spojené s charakterem keramické hmoty, tvarováním keramiky, výpalem keramiky, případně povrchovými úpravami a dalšími znaky vzniklými při používání či archeologizaci nádob. V suterénu č. 0518 bylo definováno dvanáct KT (příloha 1; podrobně viz Duffek et al. 2017).

Hlavní nápln̆ objektu tvoří KT 1-5, které se vyskytují v celém suterénu č. 0518 a jsou obsaženy ve všech skupinách vrstev v podobném poměrném zastoupení (tab. 1). Při analýze KT v jednotlivých vrstvách nebyla zjištěna vazba KT na určitou vrstvu. Podobný obsah KT v jednotlivých skupinách vrstev včetně spodního nášlapového horizontu svědčí o zaplňování objektu nedlouho po jeho zániku.

Keramické tř́ídy 1-5 patří nejstarším horizontům keramiky v suterénu č. 0518, jde o keramiku druhé poloviny 13. až počátku 14. století. Tvarově v nich převažují hrnce, objeví se fragmenty poklic - zvonovitých a kónických, džbánu, kahanu a misky (tab. 2). Dále byly sledovány typy okrajů, výzdoba či další znaky (typáře - viz př́loha 2 a 3). Početně není soubor natolik reprezentativní, aby bylo možné sledovat další vlastnosti jako vazbu KT na výzdobu, vazbu výzdoby na typ okraje atd.

Keramické třídy 1 a 2 jsou charakteristické lesklým, snad grafitovým nátěrem a liší se pouze zrnitostí (u KT 1 střední a u KT 2 jemná). Páleny byly redukčně, část fragmentů nese na 
povrchu oxidační přežah. Jejich rozlišení na základě zrnitosti je do značné míry subjektivní, proto jsou tyto dvě tř́idy vyhodnoceny společně. Ke KT 1 patří tři fragmenty okraje džbánu z jednoho jedince o průměru okraje $100 \mathrm{~mm}$, jde o okruží (DZ.1.1; obr. 4:1). Dále bylo určeno 36 okrajů hrnců (tab. 3). Výzdoba se vyskytla na 21 fragmentech výdutí (z 266 výdutí). Šlo o výzdobu na výdutích nádob v podobě variant rýh, žlábků či vlnic, případně kombinace těchto prvků (tab. 4). Ze 17 fragmentů den stojí za zmínku dno se značkou s motivem kola s šesti příčkami (obr. 6:6).

Nejpočetnější KT je redukčně pálená keramika, v některých případech opět s oxidačním přežahem povrchu a s vyšším obsahem jemné slídy patřící KT 3. Převažují v ní hrnce o průměrech 90-250 mm, nejčastěji 140-160 mm (obr. 5:1, 2, 4). Typy okrajů byly určeny u 51 kusů (tab. 3). Na 31 fragmentech výdutí, převážně na plecích, se nacházela výzdoba - nejčastěji kombinace vlnic a rýh či žlábků, př́ípadně motivy pouze s rýhami, žlábky či vlnicemi (tab. 4). Ze 76 fragmentů den nesou čtyři výrobní stopy a 21 značky. Na třech dnech se nacházely stopy po dřevěné podložce (obr. 6:12), na jednom stopy po odříznutí z hrnčířského kruhu. V této třídě se setkáme s největším zastoupením hrnčířských značek - nese je 21 fragmentů den - jde

\begin{tabular}{|c|c|c|c|c|c|c|c|}
\hline KT / Tvar & Hrnec & Džbán & Poklice zvonovitá & Poklice kónická & Poklice & Kahan & Miska \\
\hline 1 & 26 & 3 & & & & & \\
\hline 2 & 13 & & & & & & 1 \\
\hline 3 & 101 & 1 & 7 & 2 & & 3 & \\
\hline 4 & 12 & & 7 & & & 1 & \\
\hline 5 & 25 & & 14 & 3 & 1 & 3 & 1 \\
\hline Celkem & 177 & 4 & 14 & & & & \\
\hline
\end{tabular}

Tab. 2. Zastoupení keramických tvarů v KT 1-5. Hrnce určeny jen na základě okrajů.

Tab. 2. Vorkommen der Keramikformen in den Keramikklassen 1-5. Die Töpfe wurden lediglich anhand ihren Rändern bestimmt.

\begin{tabular}{|c|c|c|c|c|c|c|}
\hline Střechovitý & Ovalený & $\begin{array}{l}\text { Vodorovně } \\
\text { vyložený }\end{array}$ & Vzhůru vytažený & $\begin{array}{c}\text { Vzhůru vytažený } \\
\text { nízký }\end{array}$ & $\begin{array}{c}\text { Vzhůru vytažený } \\
\text { zúžený }\end{array}$ & $\begin{array}{l}\text { Ploché } \\
\text { okruži }\end{array}$ \\
\hline 6 & & & 5 & 4 & 5 & 1 \\
\hline 2 & 1 & 2 & 1 & 2 & & 4 \\
\hline 10 & 3 & 1 & 15 & 12 & 4 & 4 \\
\hline 0 & 1 & & 7 & 1 & 1 & \\
\hline 9 & 1 & & 3 & 5 & 1 & \\
\hline 29 & 5 & 3 & 30 & 24 & 11 & 9 \\
\hline
\end{tabular}

Tab. 3. Okraje hrnců v KT 1-5. Podrobně jednotlivé podtypy a varianty v př́loze 2.

Tab. 3. Topfränder in den Keramiklassen 1-5. Detaillierte Beschreibung der einzelnen Untertypen und Varianten in Anhang 2 .

\begin{tabular}{|c|c|c|c|c|c|c|}
\hline $\begin{array}{c}\text { KT / Typ } \\
\text { výzdoby }\end{array}$ & $\begin{array}{c}\text { Rýhy } \\
\text { (do 2 mm) }\end{array}$ & $\begin{array}{c}\text { Žlábky } \\
\text { (do 2 mm) }\end{array}$ & $\begin{array}{c}\text { Jednoduché } \\
\text { vlnice do 2 mm }\end{array}$ & $\begin{array}{c}\text { Jednoduché vlnice } \\
\text { nad 2 mm }\end{array}$ & $\begin{array}{c}\text { Kombinace vlnic } \\
\text { a rýh/žlábků }\end{array}$ & $\begin{array}{c}\text { Obloukovité } \\
\text { vrypy }\end{array}$ \\
\hline 1 & 9 & 2 & 5 & 1 & 4 \\
\hline 2 & 3 & 4 & 6 & & 17 \\
\hline 3 & 7 & 1 & 8 & 1 & 2 \\
\hline 4 & 7 & 9 & 16 & & & 24 \\
\hline 5 & 26 & & 19 & & 2 \\
\hline
\end{tabular}

Tab. 4. Základní druhy výzdoby v KT 1-5. Podrobně v př́loze 3.

Tab. 4. Grundverzierungsarten in den Keramiklassen 1-5. Detailliert in Anhang 3. 


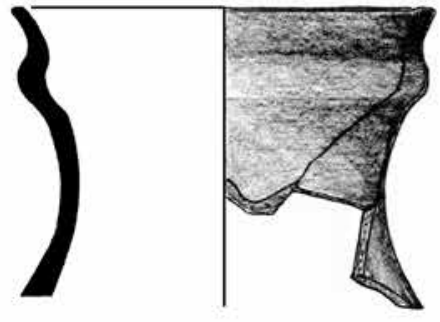

1
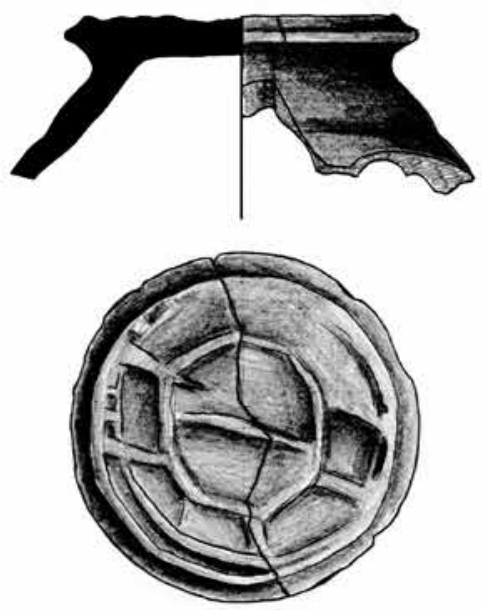

3

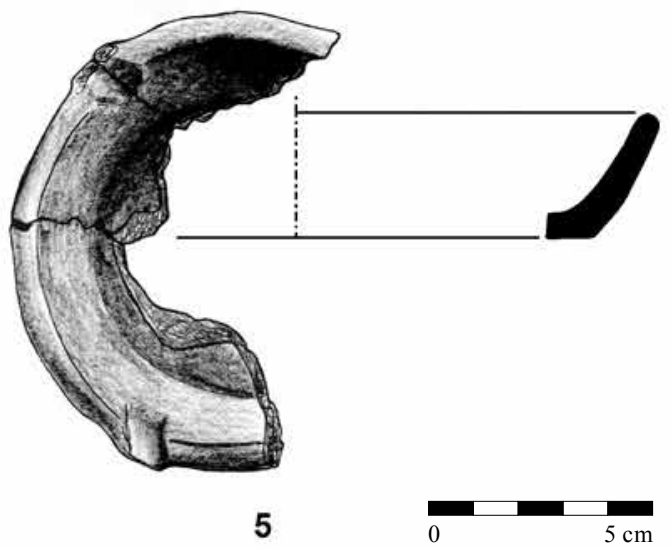

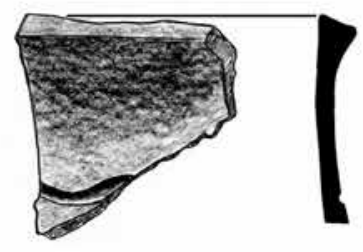

2
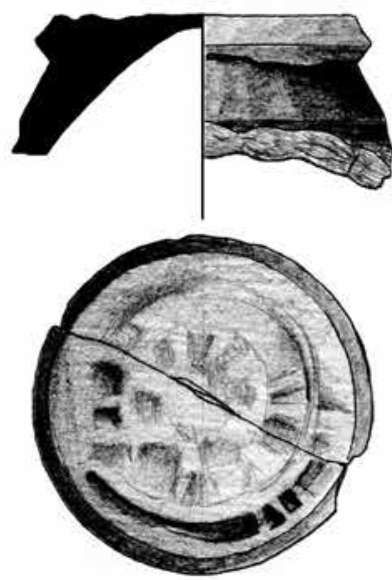

4

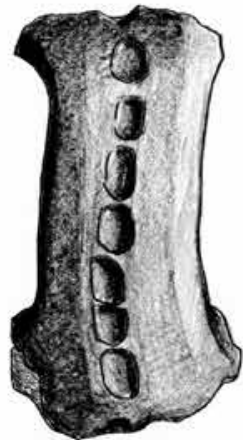

6

Obr. 4. Kresebná dokumentace keramických tvarů v suterénu č. 0518. 1 - hrdlo džbánu (JiA 112/2015-326, 349; vr. 169; KT 1); 2 - fragment misky (JiA 112/2015-334; vr. 171; KT 3); 3 - úchytka poklice se značkou (JiA 112/2015-334; vr. 171; KT 3); 4 - úchytka poklice se značkou (JiA 112/2015-334; vr. 173; KT 7); 5 - kahan (JiA 112/2015-330, 350; vr. 194, 202; KT 3); 6 - ucho patrně džbánu (JiA 112/2015-336; vr. 173; KT 3). Kresba E. Bílková-Šámalová, upravil P. Duffek.

Abb. 4. Zeichendokumentation der Keramikformen im Souterrain Nr. 0518. 1 - Hals eines Kruges (JiA 112/2015-326, 349; Schicht 169; KK 1); 2 - Schüsselfragment (JiA 112/2015-334; Schicht 171; KK 3); 3 - Deckelhalter mit Marke (JiA 112/2015334; Schicht 171; KK 3); 4 - Deckelhalter mit Marke (JiA 112/2015-334; Schicht 173; KK 7); 5 - Öllämpchen (JiA 112/2015330, 350; Schicht 194, 202; KK 3); 6 - offenbar Henkel eines Kruges (JiA 112/2015-336; Schicht 173; KK 3). Zeichnungen E. Bílková-Š́ámalová, bearbeitet von P. Duffek. 


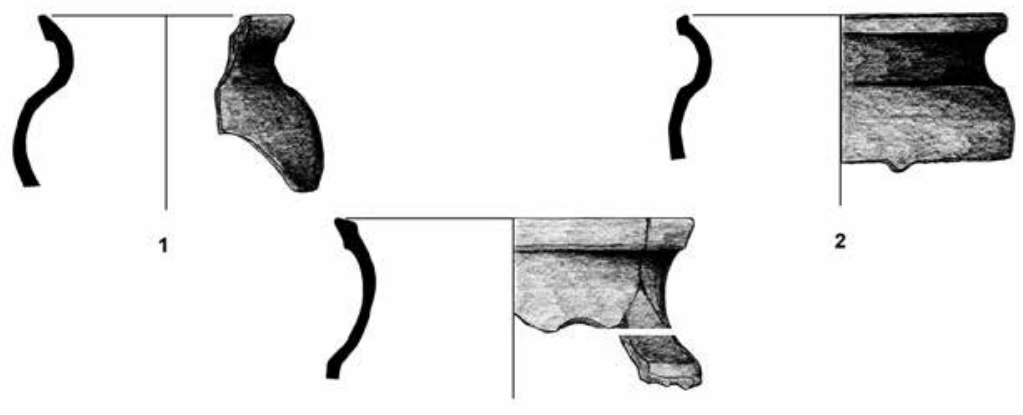

3

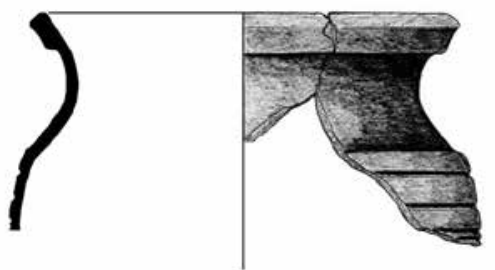

4

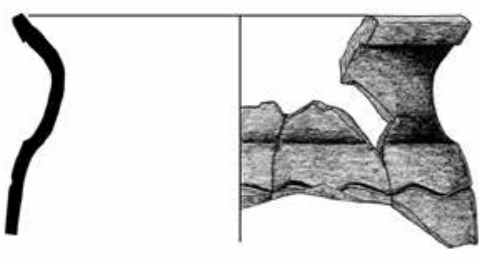

5
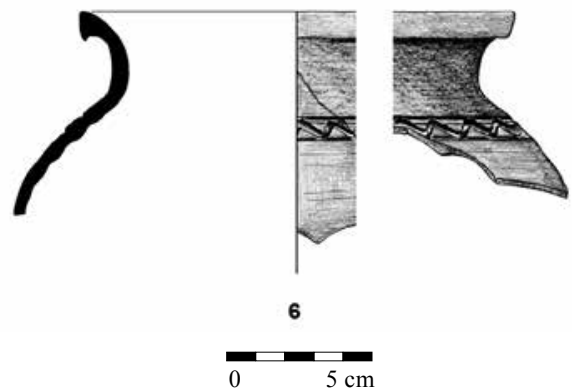
335 (vr. 171, 172, 202, 194, KT 3); 3 - JiA 112/2015-316, 334 (vr. 171, 190; KT 5); 4 - JiA 112/2015-0336 (vr. 173; KT 3); 5 - JiA 112/2015-0348; 6 - JiA 112/2015-336, 337 (vr. 173, 194; KT 7). Kresba E. Bílková-Šámalová, upravil P. Duffek.

Abb. 5. Zeichendokumentation der Topftorsi im Souterrain Nr. 0518. 1 - JiA 112/2015-334 (Schicht 171; KK 3); 2 - JiA 112/2015-330, 331, 335 (Schicht 171, 172, 202, 194, KK 3); 3 - JiA 112/2015-316, 334 (Schicht 171, 190; KK 5); 4 - JiA 112/2015-0336 (Schicht 173; KK 3); 5 - JiA 112/2015-0348; 6 - JiA 112/2015-336, 337 (Schicht 173, 194; KK 7 ). Zeichnungen E. Bílková-Š́ámalová, bearbeitet von P. Duffek.

o kruhové motivy - soustředné kruhy spojené příčkami, kruh dělený příčkami na čtvrtiny, šestiny či osminy a další, ve dvou př́ípadech se objevil na kraji kruhu motiv B (obr. 6:2, 4, 5, 7, 8, 11).

Vedle hrnců se v KT 3 vyskytly džbán (ucho), kahan (3 fragmenty zahrnující celý profil patrně patř́ící 1 jedinci), miska (okraj), poklice kónické ( 2 fragmenty úchytky z 1 jedince) a zvonovité (4 okraje, 3 fragmenty úchytek; tab. 2). Ucho džbánu bylo zdobeno vertikálně důlky promáčknutými prsty (obr. 4:6). Kahan má průměr okraje 110-120 mm a dna $80 \mathrm{~mm}$ (obr. 4:5). Výška nádoby je $30 \mathrm{~mm}$. Na umístění knotu je okraj přizpůsoben lehkým vymáčknutím okraje. Typ okraje je KA.1.1. Miska měla průměr okraje $110 \mathrm{~mm}$ a typ okraje MI.1.1 (obr. 4:2), zdobená byla vysokou vlnicí. Průměry okrajů zvonovitých poklic byly mezi $140-200 \mathrm{~mm}$. Typy okrajů: PZ.2.2, dvakrát PZ.2.3 a PZ.3.2. Na dvou úchytkách byl setřelý fragment značky či otisk desky (obr. 4:3). 


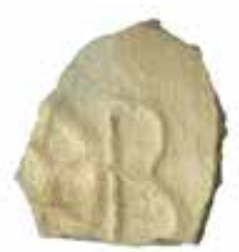

1

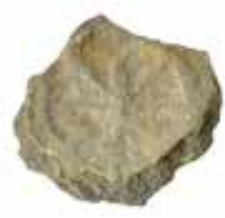

4

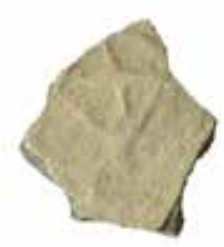

7

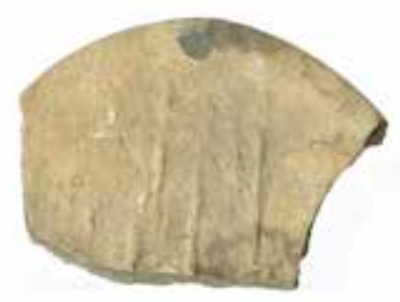

10

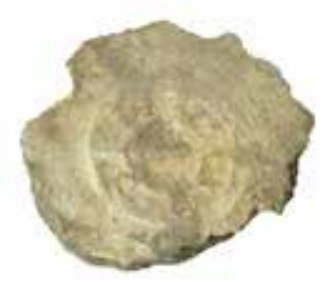

2

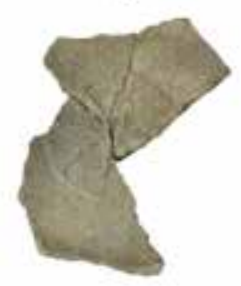

5

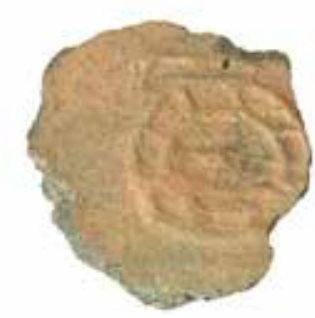

8

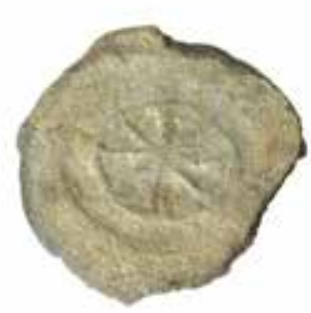

11

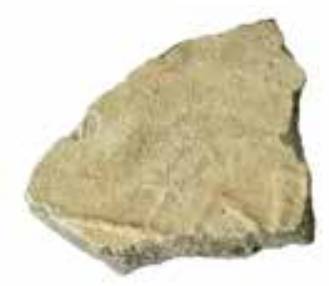

3

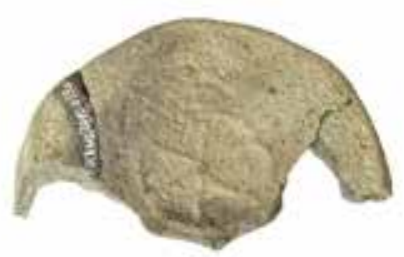

6

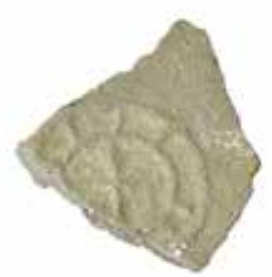

9

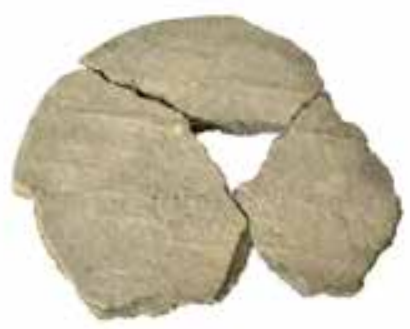

12

0

$10 \mathrm{~m}$

Obr. 6. Fotografická dokumentace značek na dnech keramických nádob ze suterénu č. 0518. 1 - JiA112/2015-336 (vr. 173; KT 5); 2 - JiA112/2015-348 (vr. 182; KT 3); 3 - JiA112/2015-337 (vr. 194; KT 4); 4 - JiA112/2015-337 (vr. 194; KT 3); 5 - JiA112/2015-337, 350 (vr. 194; KT 3); 6 - JiA112/2015-350 (vr. 194; KT 1); 7 - JiA112/2015-326 (vr. 169; KT 3); 8 JiA112/2015-349 (vr. 169; KT 3); 9 - JiA112/2015-349 (vr. 169; KT 5); 10 - JiA112/2015-334 (vr. 171; KT 7); 11 - JiA112/2015331 (vr. 171, 182; KT 3); 12 - JiA112/2015-327, 336 (vr. 173; KT 3). Foto P. Duffek.

Abb. 6. Fotodokumentation der Bodenmarken der Keramikgefäße aus dem Souterrain Nr. 0518. 1 - JiA112/2015-336 (Schicht 173; KK 5); 2 - JiA112/2015-348 (Schicht 182; KK 3); 3 - JiA112/2015-337 (Schicht 194; KK 4); 4 - JiA112/2015337 (Schicht 194; KK 3); 5 - JiA112/2015-337, 350 (Schicht 194; KK 3); 6 - JiA112/2015-350 (Schicht 194; KK 1); 7 JiA112/2015-326 (Schicht 169; KK 3); 8 - JiA112/2015-349 (Schicht 169; KK 3); 9 - JiA112/2015-349 (Schicht 169; KK 5); 10 - JiA112/2015-334 (Schicht 171; KK 7); 11 - JiA112/2015-331 (Schicht 171, 182; KK 3); 12 - JiA112/2015-327, 336 (Schicht 173; KK 3). Foto P. Duffek. 


\begin{tabular}{|c|c|c|c|c|c|}
\hline KT / Technologická stopa & Války & Války, vymačkávání & Vymačkávání & Válek nad dnem & $\begin{array}{c}\text { Války, papilární } \\
\text { linie }\end{array}$ \\
\hline 1 & 5 & & 3 & & 4 \\
\hline 2 & 3 & & & & \\
\hline 3 & 1 & & 1 & 3 & \\
\hline 4 & 2 & & & & \\
\hline 5 & 2 & 1 & & & \\
\hline Celkem & 13 & 1 & 4 & 3 & 4 \\
\hline
\end{tabular}

Tab. 5. Určené výrobní stopy na fragmentech KT 1-5 svěděí o převaze obtáčené keramiky vyráběné z válků. Spodní části nádob byly v některých př́ípadech vytvarovány či dotvarovány vymačkáváním. V menším měřítku se v souboru vyskytuje keramika vyráběná profilujícím obtáčením a vytáčením.

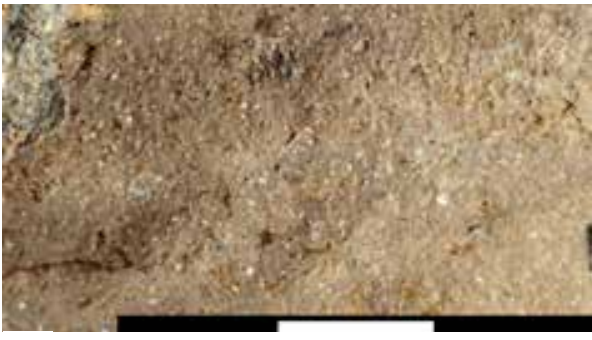

1

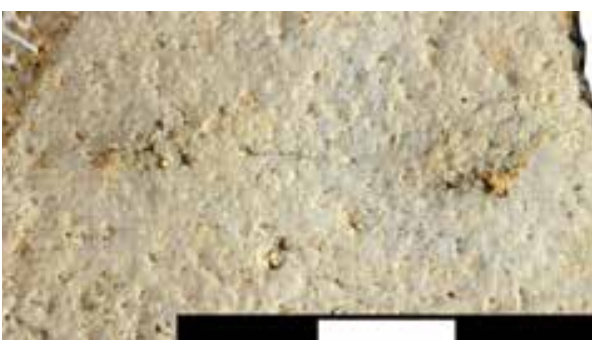

3

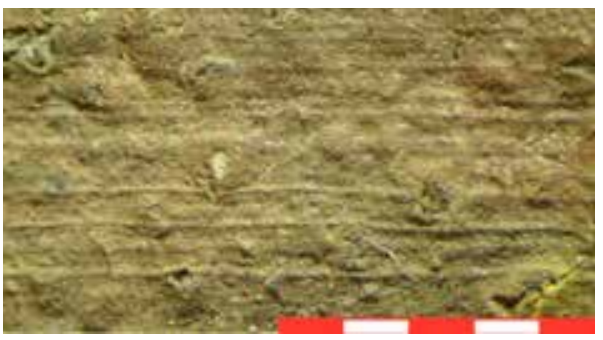

5

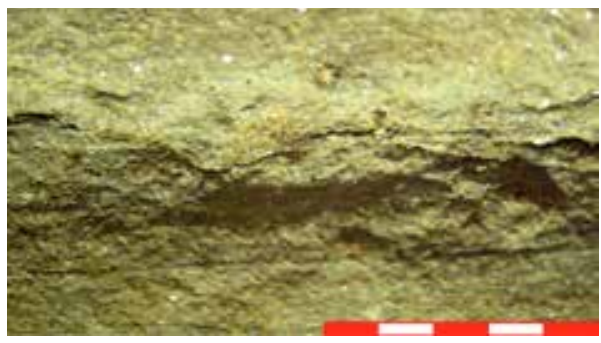

2

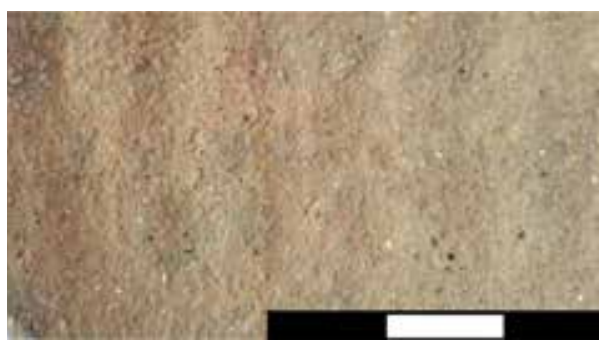

4

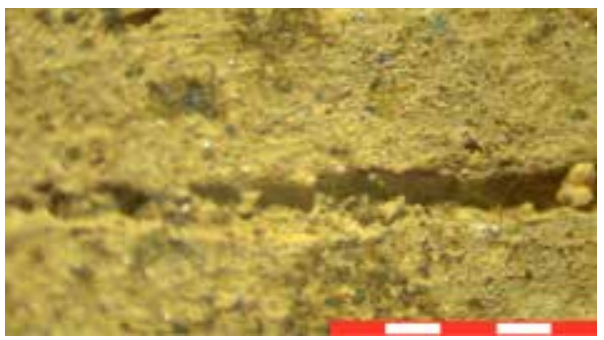

6 


\begin{tabular}{|c|l|l|l|l|l|}
\hline Nerovnoměrná stěna & $\begin{array}{c}\text { Papilární linie, } \\
\text { nerovnoměrná stěna }\end{array}$ & $\begin{array}{c}\text { Papilární } \\
\text { linie }\end{array}$ & Vytáčení & $\begin{array}{c}\text { Papilární linie, } \\
\text { prstence }\end{array}$ & $\begin{array}{c}\text { Trhlina po } \\
\text { vytáčení }\end{array}$ \\
\hline & & 3 & 3 & & \\
\hline & & 3 & & & 1 \\
\hline 1 & & 1 & & & 1 \\
\hline 2 & 5 & & & & 1 \\
\hline 3 & 5 & 11 & 3 & 1 & 1 \\
\hline
\end{tabular}

Tab. 5. Die auf den Fragmenten der Keramikklassen 1-5 festgestellten Herstellungspuren deuten auf eine überwiegend aus Tonwülsten hergestellte, abgedrehte Keramik hin. Der untere Teil der Gefäße wurde in einigen Fällen mit der Quetschtechnik ausgeformt bzw. in ihre endgültige Form gebracht. In geringerem Maße kommt in der Gruppe Keramik vor, die durch Profilabdrehen und Ausdrehen hergestellt wurde.

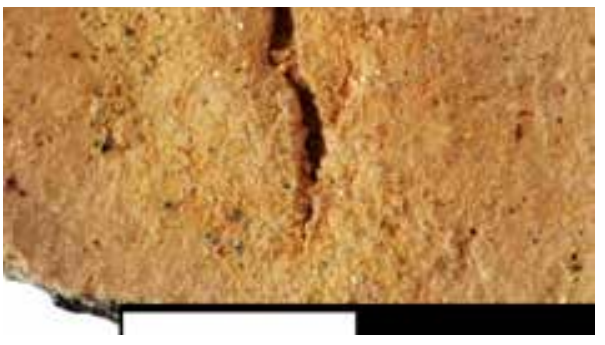

7

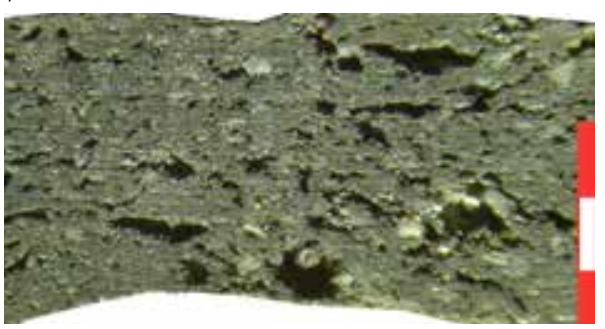

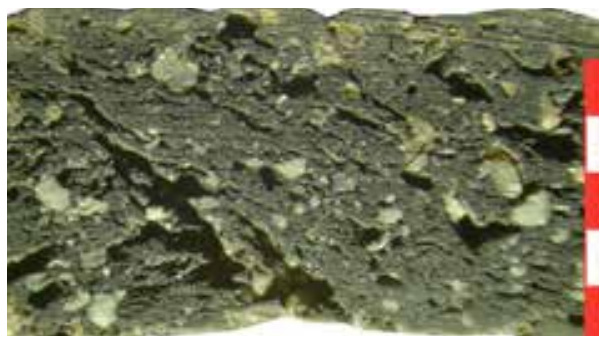

8

9

Obr. 7. Znaky související s formováním keramických nádob na KT 1-5. 1 - stopy po válcích - patrné nerovnosti a místa spojů; 2 - jemná prasklina v místě spoje válků; 3 - vakuoly - nedokonalé zahlazení spojů válků; 4 - vymačkávání - zužování a rozšiřování stěn; 5 - otisky papilárních linií - doklad využití rotace při výrobě nádoby; 6 - přemístění ostřiva ve stěně nádoby - doklad vytáčení či profilujícího obtáčení; 7 - trhlina ve stěně vzniklá př̌i vytáčení; 8 - obtáčení - šikmá orientace pórů podle válků; 9 - vytáčení - podélné uspořádání pórů. 1-7 - vnitřní stěna nádoby; 8,9-nábrus vertikálního řezu střepem; měřítko - šedé v mm, černé v cm; výběr omezen pro černobílý tisk. Podrobně včetně barevné fotodokumentace dalších technologických znaků viz Duffek et al. 2017.

Abb. 7. Mit der Formung von Keramikgefäßen zusammenhängende Merkmale an den Fragmenten der Keramikklassen 1-5. 1 - Tonwulstspuren - erkennbare Unebenheiten und Nahtstellen; 2 - feiner Riss an der Nahtstelle der Tonwülste; 3 - Vakuolen - unvollkommene Glättung der Tonwulstnahtstellen; 4 - Quetschtechnik - Verdünnen und Verdicken der Wandung; 5 - Papillarlinienabdrücke - Beleg dafür, dass bei der Herstellung des Gefäßes mit Rotationen gearbeitet wurde; 6 - Verlagerung der Magerung in der Gefäßwandung - Beleg für Ausdrehen bzw. Profilabdrehen; 7 - beim Ausdrehen in der Wandung entstandener Riss; 8 - Abdrehen - schräge Ausrichtung der Poren gemäß den Tonwülsten; 9 - Ausdrehen - Längsanordnung der Poren. 1-7 - Innenwandung des Gefäßes; 8, 9 - Querschliff eines vertikalen Scherbenschnitts; Maßstab - grau in mm, schwarz in cm; begrenzte Auswahl für Schwarz-Weiß-Druck. Detailliert einschließlich Farbfotodokumentation weiterer technologischer Merkmale siehe Duffek et al. 2017. 


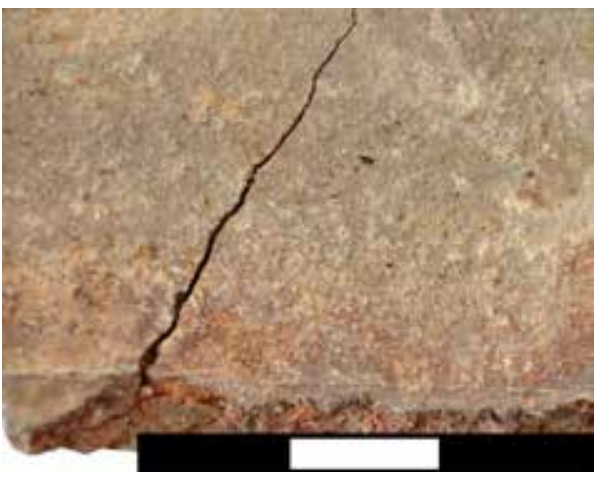

1

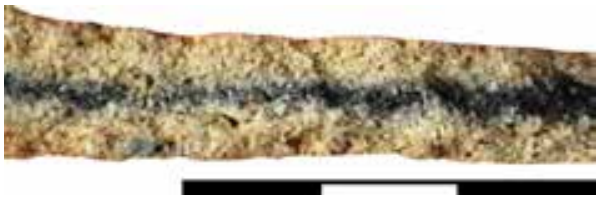

3

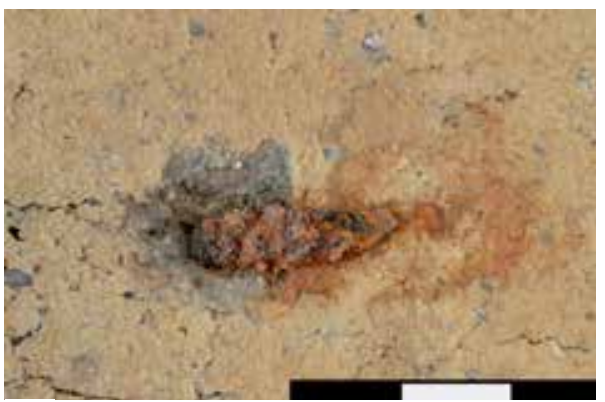

5

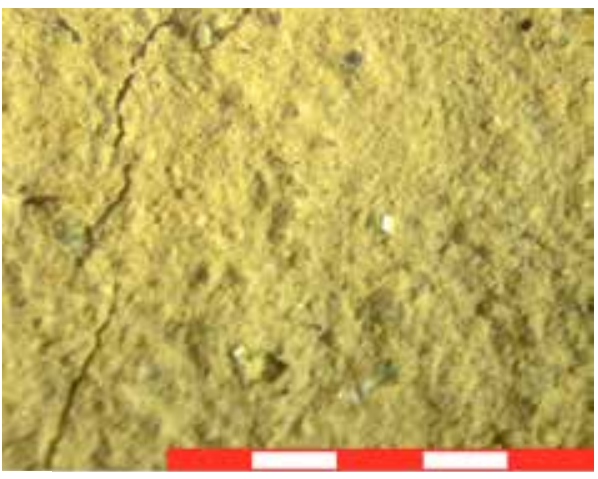

2

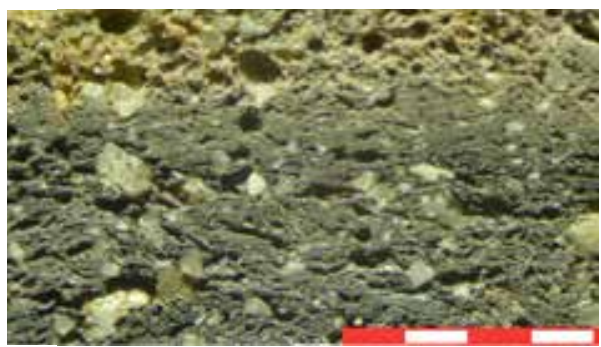

4

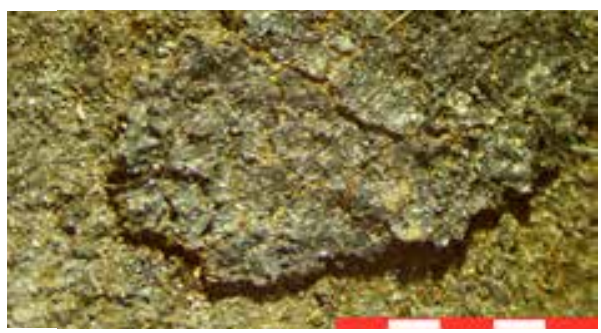

Obr. 8. Znaky související s výpalem, používáním a postdepozičními procesy na fragmentech keramických nádob KT 1-5.1prasklina vzniklá př́i výpalu tzv. teplotním šokem; 2 - drobná prasklina vzniklá při výpalu tzv. teplotním šokem; 3 - zbytek tmavého jádra v jinak oxidačně vypáleném střepu; 4 - sekundární přepálení na vnějším povrchu keramiky; 5 - makrozbytky na stěně zásobnice; 6 - reparace stěny zásobnice kovovou svorkou. 1, 2,5 - vnitřní strana fragmentu; 6 - vnější strana, 3 - čerstvý lom; 4 - nábrus vertikálního řezu střepem; měřítko - šedé v mm, černé v cm; výběr omezen pro černobílý tisk. Podrobně věetně barevné fotodokumentace dalších technologických znakủ viz Duffek et al. 2017.

Abb. 8. Mit dem Brand, der Nutzung und den postdepositären Prozessen zusammenhängende Merkmale an den Fragmenten der Keramikgefäße der Keramikklassen 1-5. 1 - Durch sog. Hitzeschock beim Brand entstandener Riss; 2 - kleiner, durch sog. Hitzeschock beim Brand entstandener Riss; 3 - Rest des dunklen Kerns im ansonsten im Oxidationsbrand gebrannten Scherben; 4 - sekundäres Überbrennen an der Außenoberfläche der Keramik; 5 - Makroreste an der Wandung eines Vorratsgefäßes; 6 - Reparatur der Wandung eines Vorratsgefäßes durch eine Metallklammer. 1, 2, 5 - Innenwandung des Fragments; 6 - Außenseite, 3 - frischer Bruch; 4 - Dünnschliff eines vertikalen Scherbenschnitts; Maßstab - grau in mm, rot in cm; begrenzte Auswahl für Schwarz-Weiß-Druck. Detailliert einschließlich Farbfotodokumentation weiterer technologischer Merkmale siehe Duffek et al. 2017.

V souboru je zastoupena redukčně pálená keramika (příp. s oxidačním přežahem povrchu) s malým množstvím slídy KT 4. Hrnce jsou v tř́iě zastoupeny 12 okraji o průměrech $80-180 \mathrm{~mm}$ (tab. 3). Pouze na dvou výdutích se nacházela výzdoba: v jednom př́ípadě šlo o žlábky, ve druhém o vlnici mezi dvěma žlábky (tab. 4). Z devíti fragmentů den o průměru 80-160 mm je třeba uvést dvě dna se značkami s motivy kola s šesti př́ičkami a dvěma soustřednými kružnicemi spojenými prŕčkami (obr. 6:3). Tvarově jsou v KT 4 doloženy ještě poklice: ploché i zvonovité (tab. 2). 
Průměry okrajů zvonovitých poklic jsou velmi variabilní - od 80 do $240 \mathrm{~mm}$, nejčastěji $120 \mathrm{~mm}$. Typy okrajů jsou PP.2.1, PZ.2.1, PZ.2.3. PZ.3.3 a třikrát PZ.5.1.

Keramickou tř́idu 5 tvoří keramika s obsahem grafitu v keramickém těstě. Tato keramika je pálena redukčně či s oxidačním přežahem povrchu. Grafit se v ní vyskytuje v podobě makroskopických zrnek či jemného prášku. Vedle grafitu obsahuje menší množství jemné slídy. Určeno bylo 22 okrajů hrnců s rozměry mezi 120-280 mm, nejčastěji $160 \mathrm{~mm}$ (tab. 3; obr. 5:3). Výzdoba se nacházela na 25 kusech výdutí. Jde o svazky rýh, různé podoby žlábkování, nízkou či vysokou vlnici, př́ípadně vlnici v kombinaci se žlábky. Dvakrát se objevila kombinace žlábků v nepravidelném odstupu na plecích s řadou vrypů na rozhraní hrdla a výdutě (tab. 3). Určeno bylo 17 fragmentů den o průměrech 100-180 mm. Na dvou dnech se nacházela značka (obr. 6:1, 9). Jeden fragment okraje zastupuje zvonovitou poklici (PZ.4.3) o průměru $120 \mathrm{~mm}$.

Stopy po technologii formování nádob byly zaznamenány na 49 fragmentech (tab. 5; obr. 7). Z tohoto nepř́liš početného vzorku lze usoudit, že většina keramiky patřící KT 1-5 byla vyrobena obtáčením s pomocí tvarování těl nádob $\mathrm{z}$ válků, $\mathrm{k}$ úpravě spodní části nádob bylo použito vymačkávání - v některých případech tak mohly být spodní části nádob vyrobeny z jednoho kusu hlíny ( $33 \mathrm{ks}$ ). U pěti fragmentů byla identifikována výroba vytáčením na rychle rotujícím hrnčířském kruhu. U zbylých jedenácti šlo o profilující obtáčení či vytáčení - fragmenty nenesou stopy po válcích; ty ale mohly být zcela setřeny při točení na hrnčířském kruhu s částečným využitím kinetické energie. Vyšší výskyt otisků papilárních linií u grafitové keramiky může být dán jejím hladším povrchem, který tyto stopy lépe zaznamená. Technologii výroby dokládá také několik den s otisky dřevěné desky a jedno dno se stopou po odříznutí (obr. 6:12). Dále byly sledovány znaky související s keramickou hmotou, výpalem, používáním nádob či postdepozičími procesy (obr. 8).

\section{KT 10 -zásobnice}

Zvláštní kategorii představují zásobnice (KT 10). Ty se vyskytují v situacích na Palackého náměstí po celé období středověku až do novověku, stejně jako se vyskytují ve většině vrstev suterénu č. 0518. Jsou vyrobeny z hrubozrnné hmoty s obsahem grafitu. Páleny jsou redukčně, př́ípadně mají na povrchu oxidační přežah. V objektu byly obsaženy ve všech skupinách vrstev v počtu 309 fragmentů (početně tvořily $17 \%$ fragmentů získaných z objektu, hmotností 61 \%).

Fragmenty zásobnic tvořilo 29 okrajů, 14 zdobených výdutí, 262 nezdobených výdutí a tři fragmenty dna. Průměr okrajů zásobnic se pohyboval mezi 360 až $500 \mathrm{~mm}$, nejčastěji $420 \mathrm{~mm}$. Výzdobu tvořili na výdutích různé počty žlábků či kombinace dvou vlnovek a žlábku, ojediněle se na okraji objevily obloukovité vrypy. Zásobnice byly vyráběny z válků či plátů, př́padně lehce dotáčeny. Na sedmi fragmentech bylo možné pozorovat stopy po reparování nádob pomocí vyvrtání otvoru a zpevnění železnými nýty, na pěti zuhelnatělé zbytky.

\section{Ostatni}

Z dalších KT je nejpočetnější KT 7 zastupující lehce přepálenou keramiku. K ní lze zařadit ještě silně přepálenou keramiku KT 8 . Stopy sekundárního přepálení byly rozpoznány na $17 \%$ fragmentů. Nejvíce těchto fragmentů se koncentrovalo ve spodních výplních nad nášlapovými vrstvami - u vrstev 2. skupiny tvoří téměř třetinu keramické výplně - směrem k povrchu jich ubývá (tab. 1). Do objektu se patrně dostaly s nějakou požárovou vrstvou. Zastoupeny jsou zde hrnce a zvonovité poklice (obr. 4:4; 5:5, 6). Vzhledem k tomu, že u fragmentů těchto tř́́d došlo ke změně části původních technologických stop (výpal, barva, pórovitost, složení keramické hmoty...), není zde dále podrobněji vyhodnocena.

Slídová keramika KT 6 je charakteristická tmavě šedým střepem, případně s oxidačním přežahem povrchu, redukčním výpalem a je poměrně tenkostěnná. V suterénu č. 0518 se vyskytla pouze ve skupinách vrstev 4 a 5 , její zastoupení pěti fragmenty ale nelze považovat za 
reprezentativní. Slídovou keramiku představují tři fragmenty zvonovité poklice původně z jednoho jedince a dvě výdutě patrně hrnců.

Keramická třída 9 zastupuje zakuřovanou keramiku (světlé či střredně šedé jádro a tmavě šedý povrch) vytáčenou na rychlém hrnčířském kruhu datovatelnou nejdřive na přelom 14. a 15. století. O tom, že je mladší než zbytek výplně, snad svědčí i to, že je zastoupena pouze 15 fragmenty, z nichž se většina (12) nachází v horní vrstvě výplně suterénu. Ve 12 př́padech jde o fragmenty nezdobených výdutí. Jeden fragment představuje okraj poháru a dva okraje hrnců. Několik fragmentů KT 11 a 12 představuje novověkou keramiku vytáčenou na rychle rotujícím hrnčířském kruhu.

Důležitý pro nálezovou situaci je obsah intruzí, tedy výrazně mladší keramiky, v jednotlivých vrstvách. Tu zde zastupují deseti fragmenty novověké KT 11 a 12. Jde o jemnou keramiku světlého střepu s poměrně tvrdým a kompaktním střepem pálenou v prŕípadě KT 11 oxidačně a u KT 12 je výpal spíše smíšený. Ty se nacházely i v nižších částech objektu. Jejich přítomnost lze vysvětlit pravděpodobně porušením a zničením části objektu výkopem kanalizace v roce 2011.

\section{Archeologický výzkum Mariánského náměstí}

Při plošném průzkumu Mariánského náměstí a přilehlé části Tovární ulice v Počátkách byly dokumentovány archeologické situace datované od 13. do 19. století. K nejstaršímu horizontu řadíme zahloubené objekty 1539 a 1540, nacházející se před čp. 141 a 156; keramika z 13. století byla zachycena také v předstihové sondě S01 (Duffek et al. 2017, 11-13, 19-21).

Před zahájením plošné skrývky byla položena před domem čp. 140 sonda S01 o rozměrech $1,0 \times 0,5 \mathrm{~m}$. Ta obsahovala $0,26-0,34 \mathrm{~m}$ mocnou vrstvu 0385 , navazující na geologické podloží. Vrstva 0385 obsahovala promíšený keramický materiál 13.-19. století a souvisí s likvidací terénních nerovností a přípravou terénu pro dláždění.

Období 13. a počátku 14. století odpovídají tři fragmenty. Zlomek ucha KT5 se sekundárním oxidačním přežahem povrchu a dva okraje KT 6 patřící patrně jedné nádobě, jde o střechovité okraje (S.1.2.). Přesněji datovat nelze třri výdutě zásobnic (KT 10), které by mohly také patřit danému období.

Objekt 1539 představuje oválný výkop o šířce minimálně $1,6 \mathrm{~m}$ a délce minimálně $2,5 \mathrm{~m}$, ze severu a západu porušený mladší výstavbou. Při hloubce $0,2 \mathrm{~m}$ byly na profilu zdokumentovány uloženiny středověkého stáří navazující na ploché dno.

Spodní vrstva 0393 obsahovala jeden fragment nezdobené výdutě grafitové KT 5 s oxidačním přežahem na vnější straně o velikosti $8 \mathrm{~cm}^{2}$. Vrstva 0392 obsahovala fragmenty KT 3 . Nejpočetnější byla grafitová KT 5. Šlo o tři okraje (O.2.1, V.2.1, S.1.1) a 13 kusů nezdobených výdutí. $\mathrm{Na}$ třech z nich jsou patrné války. Dále šlo o jeden fragment dna. Písková KT 3 byla zastoupena fragmenty o velikosti 3-6 $\mathrm{cm}^{2}$. Šlo o jeden přehnutý okraj (P.2.1), čtyři nezdobené výdutě, jednu zdobenou výdut's vlnicí (R.03.02) a tři dna - z toho jedno s fragmentem značky nejspíše kola s osmi př́íčkami. Zásobnice (KT 10) byly zastoupeny 16 výdutěmi o velikosti $4-7 \mathrm{~cm}^{2}$. Na jedné se nacházela žlábková výzdoba (R.02.02).

Před domem čp. 156 byl po skrývce vozovky zachycen do geologického podloží zahloubený kruhový výkop o průměru $0,8 \mathrm{~m}$, interpretovaný jako destrukce blíže neurčeného pyrotechnologického zařízení (obr. 9). Výplň 0,2 m hlubokého výkopu tvořila vrstva 0394 složená z uhlíků a písčité hlíny obalující mazanicovu čočku. Pod čočkou mazanice byly velmi slabé vrstvičky uhlíků a pod nimi ležela šedá popelovitá vrstva. Z vrstvy 0394 bylo získáno osm kusů zlomků keramiky a několik středních zlomků mazanice (Duffek et al. 2017, 11-12).

Keramická náplň odpovídá keramice ze suterénu č. 0518 . Jde o tři výdutě KT 1 , dále tři výdutě a dva fragmenty dna KT 3 . Všechny fragmenty jsou drobné, o velikosti $3-4 \mathrm{~cm}^{2}$. 


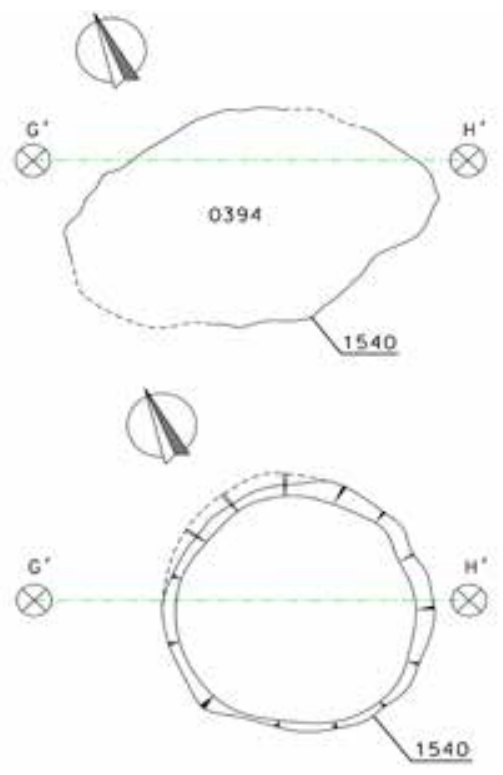

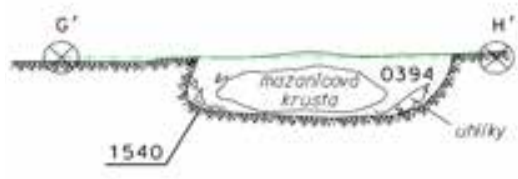

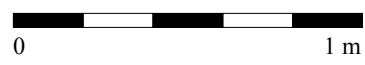

Obr. 9. Půdorys a řez pyrotechnologického zařízení 1540 z Mariánského náměstí. Digitalizace M. Daňa.

Abb. 9. Grundriss und Schnitt der pyrotechnologischen Anlage 1540 vom Marienplatz. Digitalisierung M. Daňa.

\section{Dům čp. 626 na Mariánském náměstí}

Další keramický soubor zapůjčil ke zpracování p. Matoušek. Dvě téměř kompletní keramické nádoby a několik desítek fragmentů keramiky pochází z opravy domu čp. $626 \mathrm{v}$ Počátkách probíhající v letech 1988-1991. Soubor postrádá jakoukoliv dokumentaci. Dle výpovědi majitele pochází hrneček z výkopu pod předpecní jámou u chlebové pece, ostatní nálezy byly získány $\mathrm{z}$ různých výkopů $\mathrm{v}$ průběhu rekonstrukce domu. Jde o určitou selekci fragmentů, protože v souboru převažují okraje, zdobené výdutě a dna se značkami. Vzhledem k početnosti a výběrovému složení nebyl soubor statisticky vyhodnocen. Na základě tvarů i keramické hmoty lze fragmenty datovat do 13. až počátku 14. století. Keramika odpovídá materiálu ze zahloubeného suterénu na Palackého náměstí.

Dvě téměř kompletní nádoby představují hrneček a zvonovitá poklička (obr. 10:8, 9). Oba tvary náleží KT 3 - jde o redukčně pálenou keramiku s lehkým oxidačním přežahem na povrchu. Hrneček má jednoduchý vyhnutý okraj (průměr $65 \mathrm{~mm}$ ), výšku $7 \mathrm{~cm}$ a na dně o průměru $45 \mathrm{~mm}$ se nachází značka $\mathrm{v}$ podobě kříže s kolem. Zvonovitá poklička s jednoduchým vyhnutým okrajem má průměr $140 \mathrm{~mm}$.

Okraje hrnců jsou zastoupeny 14 fragmenty. Jde o čtyři střechovité okraje (KT 3: S.2.2 a S.2.5; KT 5: S.1.1 a S.2.2), tři ovalené (KT 3: O.1.1 a O.1.2; KT 4: O.1.1), čtyři vzhůru vytažené (KT 1: V.1.1; KT 3: 2x V.1.1; KT5: V.2.3) a po jednom plochém okruží (KT 3: OP.1.2), vytaženém zužujícím se (KT 2: VZ.1.1) a vytaženém nízkém (KT 1: VN.3.1) okraji.

Vedle hrnců se v souboru nacházejí další fragmenty zvonovitých poklic. Dvě úchytky patřící KT 3 a čtyřri jednoduché vyhnuté okraje - tři patř́i KT 3 a jeden patří KT 4. Dále jde o jeden fragment kahanu s nevýraznou výlevkou promáčknutou prstem, který patř́ KT 3 (obr. 10:5). Výška kahanu byla $38 \mathrm{~mm}$, průměr dna $80 \mathrm{~mm}$ a okraje $120 \mathrm{~mm}$. Sekundárně vyrobeným tvarem z keramického fragmentu je provrtané kolečko o průměru $35 \mathrm{~mm}$ patř́ící rovněž KT 3 (obr. 10:1).

Zdobené výdutě byly zastoupeny čtyřmi malými fragmenty (obr. 10:2-4, 7). Podle typáře pro keramiku z Palackého náměstí šlo o výzdobu žlábky (KT 3: R.02.00), vlnovkami (KT 5: 


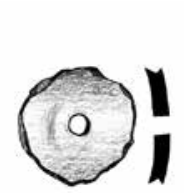

1

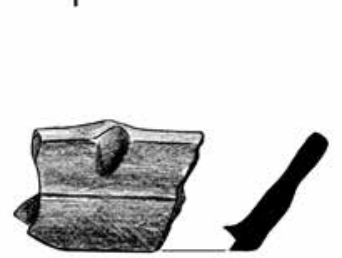

5

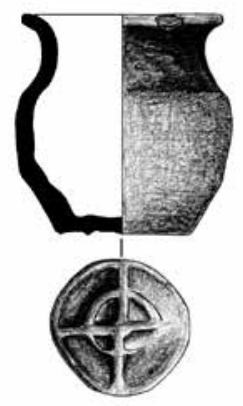

8

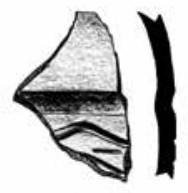

2

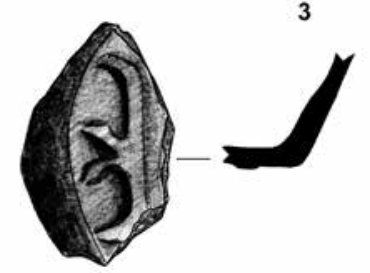

6

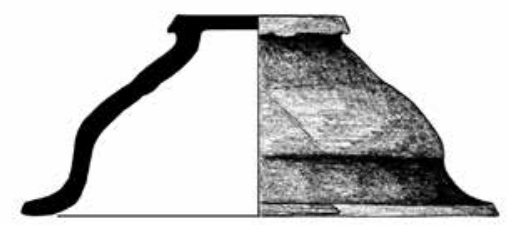

9

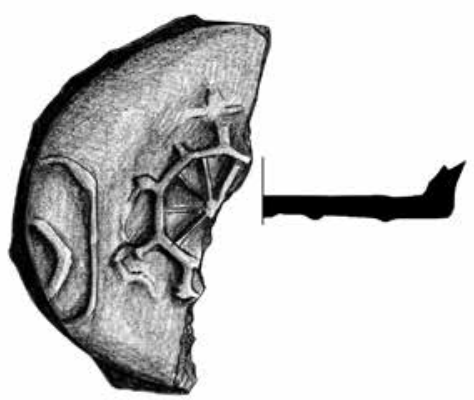

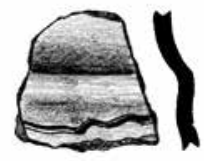

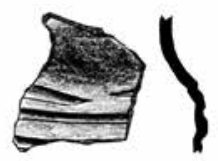

4

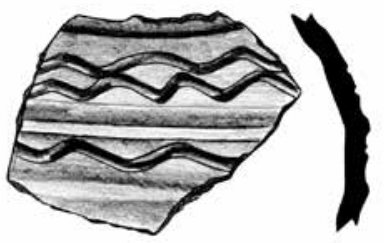

7

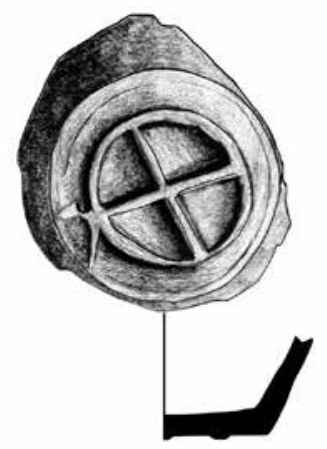

10

11

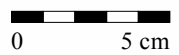

Obr. 10. Keramika ze sklepa domu čp. 626 na Mariánském náměstí. 1 - sekundárně vyrobené kolečko ze střepu, KT 3; 2 zdobený fragment lomu hrdla a výdutě, KT 3;3-zdobený fragment lomu hrdla a výdutě, KT 1; 4 - zdobený fragment lomu hrdla a výdutě, KT 3; 5 - kahan, KT 3; 6 - dno se značkou, KT 7; 7 - zdobená výdut', KT 5; 8 - hrneček se značkou na dně, KT 3; 9 - zvonovitá poklička, KT 3; 10 - dno se značkou, KT 3; 11 - dno se značkou, KT 3.

Abb. 10. Keramik aus dem Keller von Haus Konskriptionsnr. 626 am Marienplatz. 1 -aus einem Scherben sekundär hergestelltes Rädchen, Keramikklasse 3; 2 - verziertes Bruchstück von Hals und Bauch, Keramikklasse 3; 3 - verziertes Bruchstück von Hals und Bauch 1; 4 - verziertes Bruchstück von Hals und Bauch, Keramikklasse 3; 5 - Öllämpchen, Keramikklasse 3; 6 - Bodenmarke, Keramikklasse 7; 7 - verzierter Bauch, Keramikklasse 5; 8 - kleiner Topf mit Bodenmarke, Keramikklasse 3; 9 - glockenförmiger Deckel, Keramikklasse 3; 10 - Bodenmarke, Keramikklasse 3; 11 - Bodenmarke, Keramikklasse 3.

R.07.00 a KT 1: R.03.00) a kombinací vlnovek a žlábků (KT 3: R.03.00). Soubor dále obsahoval dva fragmenty den (KT 3 a KT 6) a šest kusů nezdobených výdutí (3 ks KT 3 a po 1 od KT 7, KT 8 a KT9).

Vedle značky na dně hrnečku se v souboru nacházelo dalších devět fragmentů se značkami na dnech. Dvě kompletní značky byly na nádobách KT 3. Na jednom dně byl motiv kola se dvěma kř́ži a na kraji kola s písmenem B a na druhém kř́iž s kolem (obr. 10:10, 11). Další značky se dochovaly fragmentárně: na dnech KT 7 písmeno B na kraji kruhové značky (obr. 10:6) a tři 
kruhové značky, a na dnech KT 3 fragment značky v podobě dvou soustředných kruhů spojených prríčkami, třech soustředných kruhů a část kruhové značky s příčkami.

\section{Staré sbírky - Městské muzeum Počátky}

$\mathrm{V}$ depozitáři městského muzea $\mathrm{v}$ Počátkách se nachází dvě kompletní keramické nádoby, které pochází $\mathrm{z}$ areálu města a lze je datovat do vrcholného středověku. Hrnec byl nalezen prri výkopech ve dvoře počáteckého děkanství, dnešní čp. 2. Pravděpodobně na počátku 20. století byl darován děkanem Vodrážkou do sbírek muzea. Drobná keramická láhev (inv. č. Uk 43) pochází z města Počátky, bližší nálezové okolnosti nejsou známy.

Štíhlý bezuchý hrnec patři KT 3 (obr. 11:a). Výška nádoby je $330 \mathrm{~mm}$. Hrnec má střechovitý okraj (S.2.3) o průměru $210 \mathrm{~mm}$, maximální výdut' v horní třetině (ve výšce $220 \mathrm{~mm}$ ) s průměrem $250 \mathrm{~mm}$ a dno o průměru $170 \mathrm{~mm}$. Dno nese stopy po otisku dřevěné desky a $v$ jeho středu se nachází značka v podobě kola s krř́žem, která je lehce zamáčknutá dovnitř (obr. 11:b). Na těle jsou patrné deprese. V části nad maximální výdutí je doplňuje vymačkávání. Místy jsou oba znaky patrné i zvenku (obr. 11:c). Hrnec byl patrně vyroben technologií obtáčení z válků a vrchní část byla ještě poté dotvarována.

Láhev patří slídové KT 6 (obr. 12:a). Nádoba má tělo poměrně tenkostěnné a zdobí jej jeden žlábek pod hrdlem, okraj je jednoduchý. Nachází se na ní páskové ucho. Výška nádoby je $170 \mathrm{~mm}$, průměr hrdla $30 \mathrm{~mm}$ a jeho délka $50 \mathrm{~mm}$. Maximální výdut' $(95 \mathrm{~mm})$ se nachází ve výšce $80 \mathrm{~mm}$. Dno má průměr $65 \mathrm{~mm}$. Vzhledem ke kompletnímu dochování láhve nejsou př́ípadné stopy na vnitřní stěně viditelné. Dno nese známky odříznutí nožem (obr. 12:b). Lze předpokládat, že nádoba byla vyrobena vytočením z jednoho kusu hlíny.

Obr. 11. Hrnec ze sbírek muzea v Počátkách. a - celý tvar; b - dno s hrnčířskou značkou a stopami po dřevěné podložce; $\mathbf{c}$-zvenku nádoby patrné stopy po válcích a úpravě stěn vymačkáváním.

Abb. 11. Topf aus den Sammlungen des Museums in Počátky. a - Gesamtansicht; b - Boden mit Töpfermarke und Spuren einer Holzunterlage; $\mathbf{c}$-am Gefäßäußeren erkennbare Wulst- und Bearbeitungsspuren.
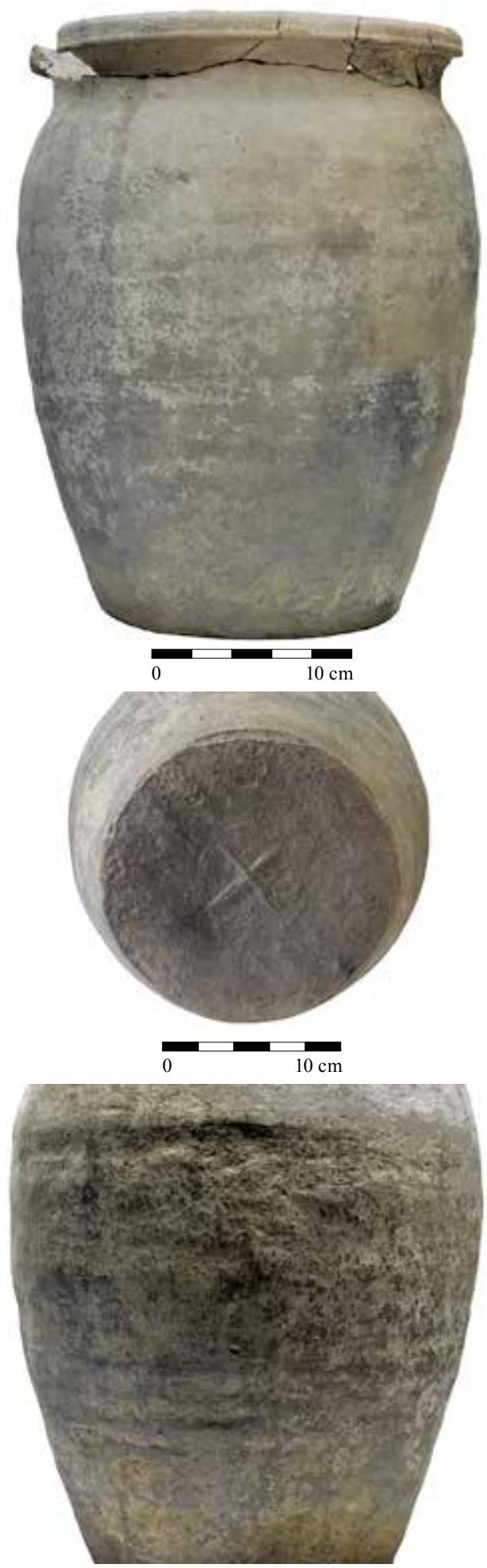


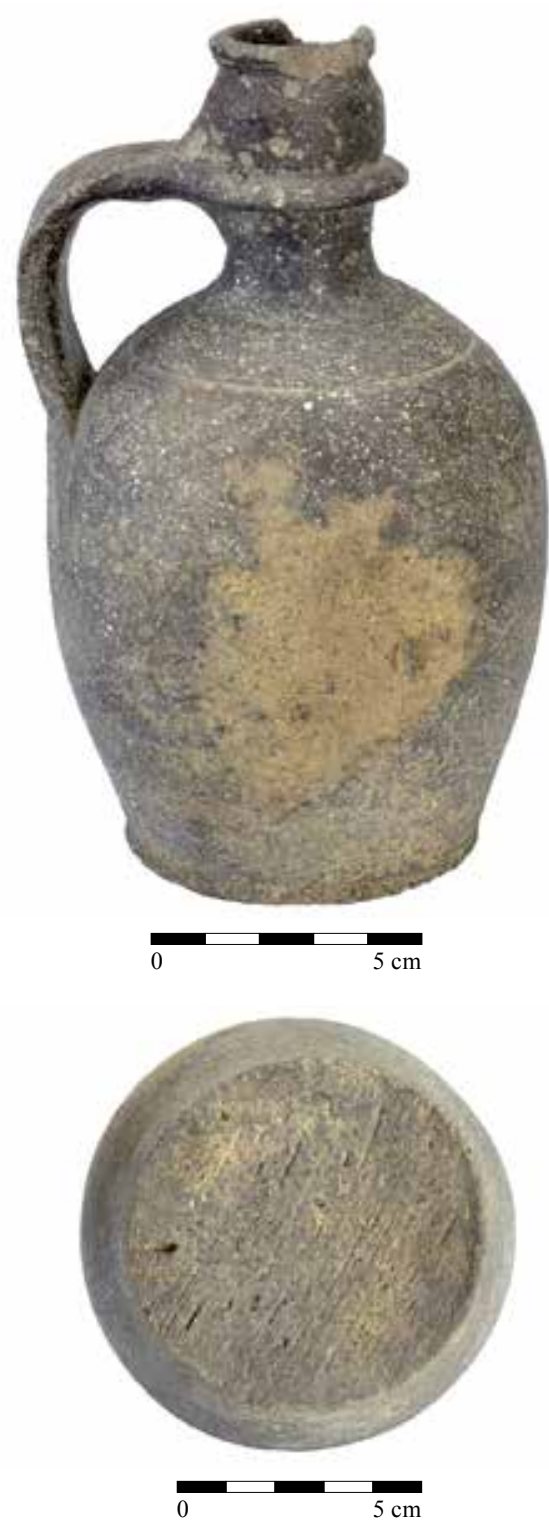

Obr. 12. Láhev ze sbírek muzea v Počátkách. a - celý tvar; b - dno se stopami po odř́źzutí nožem.

Abb. 12. Flasche aus den Sammlungen des Museums in Počátky. a - Gesamtansicht; b - Boden mit von einem Messer stammenden Abschneidespuren.

\section{Keramika 13. století z Počátek v porovná- ní s okolní produkcí}

Keramická produkce na Českomoravské vrchovině je ve 13 . a na počátku 14 . století charakteristická zvýšeným výskytem grafitové keramiky, v suterénu č. 0518 v Počátkách je jí oproti jiným lokalitám spíše méně, převažuje zde redukční keramika s př́ípadným oxidačním přežahem na povrchu a tmavým uhlíkatým jádrem. Specifická pro počátecký soubor je keramika s lesklým povrchem, snad opatřeným nátěrem. Tvarové spektrum keramiky se nevymyká obvyklému složení pro toto období s naprostou převahou hrnců, z dalších tvarů se četněji vyskytují poklice, jiné tvary jsou v souboru poměrně ojedinělé a celkově je tvarové spektrum chudé. Na lokalitě se nevyskytuje grafitová keramika zdobená rádélkem, známá $\mathrm{z}$ řady lokalit $\mathrm{v}$ regionu, která by umožnila přesnější dataci. Vyskytují se značky na dnech nádob, které jsou v tomto období běžné.

Z geograficky bližších lokalit lze srovnat materiál s keramikou z hradů Janštejn a Šternberk zaniklých v první polovině 15 . století; hlouběji do 13. století sahá soubor ze Šternberka (Bláha 1968, 148-150). Především na Šternberku lze v keramickém souboru nalézt podobné varianty střechovitých i vzhůru vytažené okraje, liší se vyšším výskytem okrajů přehnutých (Bláha 1968, 122). Na Janštejně je vyšší variabilita okrajů, vyskytují se zde rovněž střechovité a nízké vzhůru vytažené okraje (Bláha 1968, 55-57). Janštejnský keramický soubor byl nově zpracován, keramika ale nebyla rozdělena chronologicky do horizontů a obecný typář okrajů neumožňuje srovnání (Blažková 2014, 43, 77-79).

Pro další srovnání byly použity vzdálenější lokality s keramickými soubory datovanými do 13. století. Na Pelhřimovsku byla publikována keramika $\mathrm{z}$ hornického areálu Cvilínek u Černova. Podobný je výskyt vzhůru vytažených okrajů, patrně více se zde nachází okrajů ovalených. Podobné jsou výzdob-

né motivy (Hrubý et al. 2012, 385-393, obr. 85-89). Z Pelhřimova pochází keramika datovatelná do 13. století z Masarykova náměstí. Podobný je opět výskyt střechovitých a vzhůru vytažených okrajů, jiné jsou kyjovitě ovalené okraje. Na jednom dně se našla totožná značka „B“ na dně. Výzdoba zásobnic je bohatší (Hejhal-Hrubý-Malý 2005, 164-165, obr. 16-17). Soubor lze považovat za starší než počátecký. Z Humpolce byl zpracován soubor z 13. století z Horního náměstí. Oproti pelhřimovskému se v něm nacházelo méně tuhové keramiky. Ta nesla podobnou výzdobu 
vlnicemi a žlábky jako keramika v Počátkách. Okrajů se v souboru pro porovnání nacházelo málo (Hejhal-Hrubý-Malý 2005, 166, obr. 18-19).

Další možné srovnání poskytuje keramika z Telče. Publikováno bylo několik souborů, především soubor z výzkumů okolí kostela sv. Ducha. Podobný je výskyt grafitové keramiky i tvarové spektrum, v souboru převažuje obtáčená keramika, na dnech se nacházejí značky. Typy okrajů jsou variabilnější a stř̌echovité okraje se vesměs nevyskytují. Části souboru lze datovat do druhé poloviny 12. století (Bláha-Konečný 1985, 130-160; Vokáč-Zimola 2011, 51-53). Podobnější je keramický soubor ze Starého města ze Špitální ulice, kde převažují střechovité a vzhůru vytažené okraje (Vokáč-Zimola 2011, obr. 4). Nově byla zpracována keramika z výzkumu osídlení v místech dnešního Staroměstského rybníka v Telči. Soubor je podobný četnějším výskytem variant střechovitých či vzhůru vytažených především zužujících se okrajů (Běhounková 2015, obr. 1-16).

Keramická produkce ze Starých Hor u Jihlavy je ve druhé polovině 13. století (keramická skupina B) odlišná především převažujícím výskytem ovalených okrajů, je zde více přehnutých či podseknutých a méně střechovitých tvarů. Objevují se varianty vzhůru vytažených okrajů se zúžením horní části i klasických vzhůru vytažených, méně je nízkých vzhůru vytažených okrajů a plochých okruží. Výzdobné motivy jsou podobné, stejně tak výskyt značek na dnech nádob (Hrubý et al. 2006, 206-216, obr. 27-33; Zimola 2004, 32-61). Samotná Jihlava zatím nemá publikovanou podrobnější chronologickou řadu keramiky (napřr. Zimola 1996). Pro 13. století bylo z Jihlavy publikováno několik nálezů z původní osady u sv. Jana (Bláha 1968, 147). Do druhé poloviny 13. až na přelom 14. století je datován materiál z hrnčířské pece z Křížové ulice. Vsádka z pece byla deformována při výpalu, porovnat materiál tak není možné. Vyskytují se zde rovněž značená dna, keramické lampy, na hrncích se nachází výzdoba žlábkováním a mezi okraji se setkáme se střechovitou i nízkou variantou vzhůru vytaženého okraje. Celkové spektrum okrajů je ale bohatší (Zatloukal 1998, 27-29, obr. 7-9).

Z Jihlavska byla keramika 13. století publikována z několika hornických sídlišt'. Vedle Starých Hor je třeba zmínit Bedřichov u Jihlavy (Pfaffenhof), kde se nacházela grafitová keramika zdobená rýhami a žlábky. Okraje hrnců byly nejčastěji nízké vzhůru vytažené, dále střechovité, odlišné od počáteckých byly přehnuté okraje (Zimola 2012, 38-42, obr. 10). Další hornické sídliště se nacházelo v Nových Dvorech u Kamenné (u Polné). Zde byla objevena keramika 13. a 14. století s podobnými střechovitými okraji, které se zde nacházely v menším poměrném zastoupení (ačkoli soubor není dostatečně početný pro statistické porovnání). Nacházely se zde také okraje přehnuté a vzhůru vytažené. Celkově byly okraje více variabilní (Zimola 2012, 48-55, obr. 23-24).

Keramika 13. století je známá také z Kostelce. Jde o materiál z nalezené hrnčířské pece a nálezy od kostela sv. Kunhuty (Bláha 1968, 78-79, tab. 43; Zatloukal 1998, 30-31; ZimolaVokáč 2011, 435-445). Hrnčířská pec je datovaná na přelom 13. a 14. století. Okraje nalezených hrnců jsou od počáteckých poměrně odlišné, jednak je spektrum okrajů bohatší, jednak je zde výrazně nižší zastoupení okrajů střechovitých a vzhůru vytažených (Bláha 1968, 78-79, tab. 43; Zatloukal 1998, 30-31). Od kostela sv. Kunhuty pochází nepočetný soubor keramiky, ve kterém se vyskytuje grafitová keramika. Datován byl do první poloviny 13. století. Okraje hrnců jsou jiné než v počáteckém souboru - mají složitější profilaci a vyskytují se zde odlišné varianty. Soubor bohužel není dostatečně početný pro komplexnější porovnání. Vyšší výskyt vzhůru vytažených a střechovitých okrajů lze doložit také v keramickém souboru ze zaniklé stř̌edověké vsi Zhořec u Stonařova, kde se ale nacházelo i velké množství ovalených či přehnutých okrajů, a obecně zde bylo větší procento keramiky s př́íměsí grafitu. Naopak bližší je převahou nepravých okruží a kalichovitých okruží keramika 13. století ze Studnice v okrese Jihlava (Těsnohlídková b. d.).

Geograficky vzdálenější je keramika z Třebíčska. Soubory datované do 13. století ze samotné Třebíče i jejího okolí obsahují ve srovnání s počáteckou keramikou podstatně vyšší podíl grafitové keramiky, nachází se zde výzdoba rádélkem a v okrajích převažují varianty vzhůru vytažených okrajů poměrně odlišné od počáteckých (např. Vokáč 2001, 136-137; Měřínský 1988, 36). 
Ke srovnání byla použita i vzdálenější lokalita Žd'ár nad Sázavou - Staré město (2. třetina 13. století). Vyskytuje se zde rovněž řada variant střechovitých okrajů, podobně i vzhůru vytažených, na těch se často nachází výzdoba v podobě vlnice či několika rýh a jejich variabilita je mnohem větší (Těsnohlídková b. d.; Zatloukal 1999, 195-205).

Z oblasti Jindřichohradecka byl publikován soubor grafitové keramiky z Veselíčka u Starého Hobzí. Jde o starší keramiku, než je počátecký soubor, podle analogií z Rakouska byla datována až do 10. století (Hejhal 2012, 144-152).

Hlavním problémem při porovnávání keramiky z Počátek $\mathrm{s}$ keramikou z okolních regionů je nejednotný způsob zpracování keramických nálezů, neexistuje např́íklad jednotný systém pro popis okrajů, případně technologie výroby nádob. Hlavně keramická hmota je někdy popsána jen velmi obecně. Ke srovnání lze tak nejlépe využít kresebnou dokumentaci u publikovaných souborů, která je v řadě případů jen málo početná a u níž není jasné, zda odráží reprezentativní vzorek. Některé soubory jsou navíc poměrně málo početné a pocházejí ze sběrů či drobných výzkumů. Přri porovnání keramické technologie lze srovnávat většinou pouze výskyt grafitové keramiky či redukčně/oxidačně pálené zboží, například stopy po formování keramiky jsou sledovány jen v málo souborech, př́ípadně lze na způsob formování poukázat třeba z výskytu den se značkami - což je dáno i vysokou fragmentarizací u většiny publikovaných souborů. Srovnání také ztěžuje nedostatek či absence publikovaných souborů v některých oblastech, především na Jindřichohradecku.

Obecně lze říci, že tvarově se počátecká produkce 13. století nevymyká obvyklému složení pro toto období s naprostou př̀vahou hrnců. Pro keramickou produkci Českomoravské vrchoviny 13. století je typická vysoká variabilita okrajů hrnců s lokálními variantami a typy. Oproti jiným souborům je v tomto menší podíl grafitové keramiky. Menším podílem „kolonizačních prvků“, jako jsou ploché poklice, džbány a hrnce s okraji stř̌echovitých a přehnutých tvarů, má keramika z Počátek blíže k specifické produkci Českomoravské vrchoviny než k produkci jihomoravské (Procházka-Peška 2007, 143-232; Hrubý et al. 2006, 208-215).

\section{Závěr}

Cílem studie bylo zpracování archeologických situací z Počátek, které lze datovat do 13. a na počátek 14. století. Město vzniklo na dálkové trase Jihlava - Jindřichův Hradec, přičemž původní centrum mělo protáhlý vřetenovitý tvar a teprve na počátku 16. století bylo při výstavbě hradeb zmenšeno do současného půdorysu.

Těžištěm práce bylo zpracování keramických souborů zkoumaného období a podchycení charakteru kuchyňského a stolního zboží první fáze existence města. Zpracováno bylo několik keramických souborů. Jako základ pro tvorbu keramických tř́íd a typářù okrajů a výzdoby byl použit soubor ze zahloubeného suterénu z Palackého náměstí. Další keramika už byla zpracována na základě těchto typářů.

Nejpočetnějším zpracovaným souborem je soubor ze zahloubeného suterénu objeveného při archeologickém výzkumu Palackého náměstí. Na základě vlastností keramických nálezů lze vrstvy při dně suterénu č. 0518 interpretovat jako nášlapové, ostatní představují zásypy objektu. Tvarově převažují hrnce, objeví se fragmenty poklic, džbánu, kahanu a misky. Mezi okraji hrnců převažují vzhůru vytažené, střechovité a vzhůru vytažené nízké, početněji jsou zastoupeny okraje vzhůru vytažené nahoře zúžené a plochá okruží. Výzdobu nádob představují rýhy, žlábky či vlnice, případně jejich kombinace, ojediněle vrypy. Na dnech nádob či úchytkách poklic se vyskytují značky. Většina fragmentů, u kterých bylo možné určit způsob výroby, nesla stopy po obtáčení.

Další zpracované soubory jsou již o poznání drobnější. Jde o několik fragmentů ze sondy a ze dvou objektů z výzkumu Mariánského náměstí. Dále byla zpracována keramika získaná vlastníkem domu při rekonstrukci domu čp. 62 na Mariánském náměstí. Dvě kompletní nádoby datovatelné do 13.-14. století se nacházejí ve sbírkách muzea v Počátkách. 
Možnost porovnání keramiky s nálezy z okolních regionů omezuje absence publikovaných souborů. Menším podílem ,kolonizačních prvkư“, jako jsou ploché poklice, džbány a hrnce s okraji střechovitých a přehnutých tvarů, má keramika z Počátek blíže k specifické produkci Českomoravské vrchoviny než k produkci jihomoravské (Procházka-Peška 2007, 143-232; Hrubý et al. 2006, 208-215).

Za zapůjčení keramiky děkujeme Městskému muzeu Počátky a panu Matouškovi.

Př́íspěvek vznikl v rámci projektu NAKI II „Vrcholně středověká keramika jako součást movitého kulturního dědictvi““ číslo DG18P02OVV020.

\section{Prameny a literatura}

BĚHOUNKOVÁ, L., 2015: Keramická produkce ze středověkého sídliště Telč - Staroměstský rybník se zaměřením na technologii výroby nádoby. Rkp. diplomové práce, Ústav archeologie a muzeologie FF MU, Brno.

BLÁHA, J., 1968: Vývoj osídlení jihozápadní Moravy do doby husitské. Rkp. diplomové práce, Ústav archeologie a muzeologie FF MU, Brno.

BLÁHA, J.-KONEČNYY, L., 1985: K nejstarší historii města Telče. In: Uměleckohistorický sborník (Sedláŕ, J., ed.), 130-160. Brno.

BLAŽKOVÁ, E. M., 2014: Zpracování keramického souboru z Janštejna. Rkp. diplomové práce, Ústav archeologie a muzeologie FF MU, Brno.

ČERNOŠ, Š., 2012: Rekonstrukce ČOV a kanalizace Vesce a Palackého náměstí, nálezová zpráva, rkp. ulož. v Archaia Brno, o.p.s., č. A062/2010.

DUFFEK, P. et al., 2017: Duffek, P.-Těsnohlídek, J.-Těsnohlídková, K.-Prachařová, M.-Skořepová, M., Stavební úpravy Palackého náměstí Počátky, nálezová zpráva, rkp. ulož. v Archaia Brno, o.p.s., č. A020/2014.

DUFFEK, P.-TĚSNOHLÍDEK, J., 2017: Počátky - oprava komunikace na Mariánském náměstí, nálezová zpráva, rkp. ulož. v Archaia Brno, o. p.s., č. A043/2016.

HEJHAL, P., 2012: Raně středověké artefakty z Veselíčka u Starého Hobzí (okres Jindřichův Hradec), uložené v Muzeu Vysočiny Jihlava - Early mediaeval artefacts from Veselíčko u Starého Hobzí (district Jindřichův Hradec), deposited in depository of the Museum Vysočiny in Jihlava, AVV 3, 144-152.

HEJHAL, P.-HRUBÝ, P.-MALÝ, K., 2005: Počátky středověkého osídlení měst Pelhřimov a Humpolec $\mathrm{v}$ archeologii, AVJČ $18,135-177$.

HRUBÝ, P. et al., 2006: Hrubý, P.-Jaroš, Z.-Kočár, P.-Malý, K.-Mihályiová, J.-Militký, J.-Zimola, D., Středověká hornická aglomerace na Starých Horách u Jihlavy - Das mittelalterliche Bergbauzentrum in Staré Hory (Altenberg) bei Jihlava (Iglau), PA XCVII, 171-264.

HRUBÝ, P. et al., 2012: Hrubý, P.-Hejhal, P.-Hoch, A.-Kočár, P.-Malý, K.-Macháňová, L.-Petr, L.Štecl, J., Stř̌edověký úpravnický a hornický areál Cvilínek u Černova na Pelhřimovsku - Das mittelalterliche Aufbereitungs- und Bergbauareal Cvilínek bei Černov in der Region Pelhřimov, PA CIII, 339-418.

KOVÁŘ, D., 2016: Počátky jihočeských měst a městeček. Krátké shrnutí vývoje. In: Počátky měst a městeček v Jižních Čechách. Jihočeský sborník historický - Supplementum 7 (Kováŕ, D., ed.), 8-78. České Budějovice.

MĚŘÍNSKÝ, Z., 1988: Počátky osídlení Brtnicka a nejstarší dějiny obce. In: Dějiny Brtnice a připojených obcí, 13-49. Brno.

PROCHÁZKA, R., 2007: Deskripční systém brněnské keramiky. Př́iloha 1, PV 48, 234-270.

PROCHÁZKA, R.-PEŠKA, M., 2007: Základní rysy vývoje brněnské keramiky ve 12.-13./14. století Grundlinien der Entwicklung der Keramik von Brno im 12.-13./14. Jahrhundert, PV 48, 143-233.

TĚSNOHLÍDEK, J. et al., 2017: Těsnohlídek, J.-Duffek, P.-Těsnohlídková, K.-Prachařová, M.-Skořepová, M.-Janoušek, T.-Stančíková, M., Výsledky archeologického výzkumu Palackého náměstí v Počátkách (okres Pelhřimov) - Die Ergebnisse der archäologischen Grabung am Palacký-Platz in Počátky (Bezirk Pelhřimov), AH 42, 2017, 669-689.

TĚSNOHLÍDKOVÁ, K., b. d.: Utváření vrcholně středověké keramiky v centrální části Českomoravské vrchoviny na př́íladu vybraných keramických souborů (13. - 1. polovina 14. století). Rkp. připravované disertační práce, Ústav archeologie a muzeologie FF MU, Brno. 
VOKÁČ, M., 2001: Nové archeologické poznatky ke vzniku města Třebíče, Západní Morava 5, 130-150.

VOKÁČ, M.-ZIMOLA, D., 2011: Archeologické výzkumy opevněného dvorce s kostelem a věží sv. Ducha v Telči - Archeological researches of the fortified court with church and tower of Holy Spirit in Telč, AVV 2, 51-70.

ZATLOUKAL, R., 1998: Středověké hrnčířské pece z Jihlavy a okolí, Vlastivědný sborník Vysočiny, oddíl věd společenských 11, 27-44.

- 1999: Zpráva o archeologickém výzkumu ve Žd'áře nad Sázavou, trat' Staré Město, v letech 1996-1999. In: Mediaevalia archaeologica 1 (Ježek, M.-Klápště, J., edd.), 193-207. Praha.

ZIMOLA, D., 1996: Středověká Jihlava ve světle archeologických pramenů. Rkp. diplomové práce, Ústav archeologie a muzeologie FF MU, Brno.

- 2004: Nálezy keramiky ze Starých Hor u Jihlavy. In: Stříbrná Jihlava 2004, 32-61. Jihlava.

- 2012: Hornická sídliště v okolí Jihlavy podle archeologických pramenů - Mining settlements around Jihlava according to archeological resources, AVV 3, 27-57.

ZIMOLA, D.-VOKÁČ, M., 2011: Archeologické výzkumy několika venkovských kostelů na Jihlavsku Ländliche Sakralarchitektur in der Region Jihlava, AH 36, 431-450.

\section{Zusammenfassung}

\section{Die Archäologie des ältesten Horizonts der Stadt Počátky (Bezirk Pelhřimov)}

Ziel der vorliegenden Studie war eine Bearbeitung der archäologischen Situationen von Počátky, die man in das 13. und an den Beginn des 14. Jahrhunderts datieren kann. Die Stadt entstand an der Ferntrasse Jihlava - Jindřichův Hradec, wobei das ursprüngliche Zentrum eine langgezogene spindelartige Form hatte und erst zu Beginn des 16. Jahrhunderts während der Errichtung der Stadtmauer zum gegenwärtigen Grundriss verkleinert wurde.

Der Schwerpunkt der Arbeit lag in der Bearbeitung der Keramikkomplexe des untersuchten Zeitraums und in der Erfassung des Charakters der Küchen- und Tafelkeramik aus der ersten Phase der Existenz der Stadt. Es wurden mehrere Keramikkomplexe untersucht. Als Grundlage für die Schaffung von Keramikklassen und einer Aufstellung der Randtypen und Verzierungen wurde der Keramikkomplex aus einem eingetieften Souterrain am Palacký-Platz als Grundlage herangezogen. Die andere Keramik wurde dann bereits anhand dieser Typenaufstellungen bearbeitet.

Der am zahlreichsten vertretene Komplex wurde während der am Palacký-Platz erfolgten archäologischen Grabung in einem eingetieften Souterrain entdeckt. Anhand der Eigenschaften der Keramikfunde kann die Schicht am Boden von Objekt 0518 als Gehschicht interpretiert werden, die übrigen Schichten stellen Verfüllungen des Objektes dar. Formenmäßig überwiegen Töpfe, es tauchen auch Fragmente von Deckeln, Krügen, Öllämpchen und Schüsseln auf. Unter den Topfrändern überwiegen nach oben gezogene, dachförmige und flache, nach oben gezogene Ränder, zahlreicher vertreten sind nach oben gezogene, sich verjüngende Ränder und flache Kragenränder. Die Verzierung der Gefäße besteht aus Rillen, Riefen oder Wellenlinien, ggf. aus einer Kombination dessen, vereinzelt treten auch Ritzverzierungen auf. An den Gefäßböden bzw. Deckelgriffen befinden sich Marken. Die meisten Fragmente, bei denen die Herstellungsweise bestimmt werden konnte, trugen Abdrehspuren.

Die anderen bearbeiteten Komplexe sind schon erkennbar kleiner. Es handelt sich um mehrere Fragmente aus Sondageschnitten und aus zwei Objekten der am Marienplatz erfolgten Grabung. Ferner wurde Keramik bearbeitet, die vom Hausbesitzer des am Marienplatz Nr. 629 liegenden Hauses während seiner Renovierung entdeckt wurde. Zwei komplette in das 13.14. Jahrhundert datierbare Gefäße befinden sich in den Sammlungen des Museums von Počátky.

Die Möglichkeit die Keramik mit den Funden aus den umliegenden Regionen zu vergleichen, wird durch das Fehlen von veröffentlichten Keramikkomplexe eingeschränkt. Mit einem geringeren Anteil an „Kolonisationselementen“, wie etwa flache Deckel, Krüge und Töpfe mit dachförmigen und gebogenen Formen es sind, steht die Keramik von Počátky der speziellen 
Produktion der Böhmisch-Mährischen Höhe näher als der Produktion von Südmähren (Procházka-Peška 2007, 143-232; Hrubý et al. 2006, 208-215).

Der vorliegende Beitrag entstand im Rahmen des Projektes NAKI II „Hochmittelalterliche Keramik als Bestandteil des beweglichen Kulturerbes“ Nr. DG18P02OVV020.

Petr Duffek, Archaia Brno, o.p.s., Židovská 26, 58601 Jihlava, Česká republika, archaiajihlava@volny.cz

Mgr. Kateřina Těsnohlídková, Ústav archeologie a muzeologie Filozofické fakulty Masarykovy univerzity, Arne Nováka 1, 60200 Brno, Česká republika, tesnohlidkova@mail.muni.cz

Mgr. Jakub Těsnohlídek, Archaia Brno, o. p. s., Židovská 26, 58601 Jihlava, Česká republika, archaiajihlava@volny.cz 


\section{KT 1 - stř̌edně zrnitá s lesklým povrchem (274 fragmentů)}

Hmota: malé množství grafitu nebo nevyhořelý organický uhlík; střední až velké množství slídy - zrníčka $1 \mathrm{~mm}$; střední zrnitost

Výpal: redukční či oxidační přežah; střední tvrdost

Povrch: lesklý nátěr na vnějším povrchu, hladký

Barva: tmavě šedá, v př́ípadě oxidačního přežahu povrch: okrová, oranžová, světle hnědá, světle šedá, barva nátěru: středně až tmavě šedá

\section{KT 2 - jemně zrnitá s lesklým povrchem (80 fragmentů)}

Hmota: malé množství grafitu nebo nevyhořelý organický uhlík; přirozená příměs slídy nebo střední až velké množství slídy - zrníčka $1 \mathrm{~mm}$; jemná zrnitost

Výpal: redukční či oxidační přežah; střední tvrdost

Povrch: lesklý nátěr na vnějším povrchu, hladký

Barva: tmavě šedá, v případě oxidačního přežahu povrch: okrová, světle hnědá - světle šedá, barva nátěru: středně až tmavě šedá

\section{KT 3 - středně zrnitá se slídou (449 fragmentů)}

Hmota: malé množství grafitu nebo nevyhořelý organický uhlík; střední až velké množství slídy - zrníčka $1 \mathrm{~mm}$; střední zrnitost

Výpal: redukční či oxidační přežah; střední tvrdost

Povrch: hladký až jemně drsný

Barva: tmavě šedá, v případě oxidačního přežahu povrch: okrová, oranžová, odstíny hnědé, světle šedá, béžová

\section{KT 4 - střredně zrnitá redukční (103 fragmentů)}

Hmota: malé množství grafitu nebo nevyhořelý organický uhlík; přirozená příměs slídy; střední zrnitost Výpal: redukční či oxidační přežah; střední tvrdost

Povrch: hladký, ojediněle jemně drsný

Barva: tmavě šedá, v př́ípadě oxidačního přežahu povrch: okrová, oranžová, světle hnědá - světle šedá

\section{KT 5 - grafitová (235 fragmentů)}

Hmota: střední až velké množství grafitu bez makroskopicky pozorovatelných zrnek nebo se zrnky; přirozená příměs slídy nebo střední až velké množství slídy - zrníčka $1 \mathrm{~mm}$; střední zrnitost

Výpal: redukční či oxidační přežah; střední tvrdost

Povrch: hladký až jemně drsný

Barva: tmavě šedá, v případě oxidačního přežahu povrch: odstíny hnědé, okrová, světle šedá

\section{KT 6 - slídová (5 fragmentů)}

Hmota: malé množství grafitu nebo nevyhořelý organický uhlík; přirozená příměs slídy nebo střední až velké množství slídy - šupinky $2 \mathrm{~mm}$; stř̌ední zrnitost

Výpal: redukční či oxidační přežah; střední tvrdost

Povrch: hladký

Barva: tmavě šedá, v případě oxidačního přežahu povrch: okrová, světle šedá, odstíny hnědé

\section{KT 7 - lehce přepálená keramika (307 fragmentů)}

Hmota: bez grafitu či malé množství, ojediněle grafitová; přirozená příměs slídy nebo střední až velké množství slídy - zrníčka $1 \mathrm{~mm}$; střední zrnitost

Výpal: smíšený či zbytek černého jádra, mírně přepálená keramika; střední tvrdost

Povrch: jemně drsný, krupičkovitý či hladký

Barva: celá škála barev, nejednotnost barevnosti fragmentu; plynulý přechod mezi barevnými vrstvami

\section{KT 8 - přepálená keramika (1 ks)}

Hmota: přepálení znemožňuje určit složení fragmentu - bez grafitu či různé množství grafitu; přirozená příměs slídy nebo střední až velké množství slídy - zrníčka $1 \mathrm{~mm}$; nejčastěji střední zrnitost

Výpal: stř̌edně či silně přepálená keramika; střední až tvrdá

Povrch: jemně drsný

Barva: celá škála barev, nejednotnost barevnosti fragmentu; plynulý přechod mezi barevnými vrstvami 


\section{KT 9 - zakuřovaná středně tvrdá (15 fragmentů)}

Hmota: bez grafitu; prrirozená prríměs slídy; jemná nebo střední zrnitost Výpal: zakuřování; střední tvrdost Povrch: hladký

Barva: jádro - světle nebo středně šedá, povrch - tmavě či středně šedá; plynulý přechod mezi barevnými vrstvami

\section{KT 10 - zásobnice (309 fragmentů)}

Hmota: střední až velké množství grafitu se zrnky; přirozená příměs slídy; u některých možná příměs šamotu; hrubozrnná

Výpal: redukční či oxidační přežah; měkká až střední tvrdost

Povrch: jemně drsný až hladký

Barva: jádro - středně nebo tmavě šedá, povrch při oxidačním přežahu - oranžová, světle šedá, odstíny hnědé

\section{KT 11 - jemná oxidační tvrdá (novověk; 1 fragment)}

Hmota: bez grafitu; přirozená př́měs slídy; jemná zrnitost

Výpal: oxidační; tvrdá

Povrch: hladký

Barva: krémová až okrová

\section{KT 12 - smíšený výpal kompaktní hmota (novověk; 9 fragmentů)}

Hmota: obsah grafitu nelze určit; střední až velké množství slídy - zrníčka $1 \mathrm{~mm}$; jemná zrnitost Výpal: smíšený; střední tvrdost

Povrch: jemně drsný

Barva: nejčastěji světle či středně šedá, oranžová; nerovnoměrné zbarvení

Př́loha 1. Přehled a definice KT vyskytujících se na keramice z Počátek ve zpracovávaných souborech. Definováno na základě souboru ze suterénu č. 0518. Podrobná definice KT včetně fotodokumentace povrchů a lomů viz nálezová zpráva Duffek et al. 2017.

Anhang 1. Übersicht und Definition der Keramikklassen, die bei der Keramik von Počátky in den bearbeiteten Komplexen vorkommen. Definiert wurden sie anhand des Keramikkomplexes aus dem Souterrain Nr. 0518. Detaillierte Definition der Keramikklassen einschließlich Fotodokumentation der Oberflächen und Brüche siehe Fundbericht Duffek et al. 2017. 


\begin{tabular}{|c|c|c|c|c|c|c|}
\hline \multicolumn{7}{|c|}{ Základní typy okrajů hrnců, jejich podtypy a varianty } \\
\hline $\begin{array}{l}\text { Jednoduchý } \\
\text { vyhnutý }\end{array}$ & $\begin{array}{l}\text { JV.1.1 } \\
\text { (3) }\end{array}$ & & & & & \\
\hline Střechovitý & $\begin{array}{l}\text { S.1.1 } \\
(1,3)\end{array}$ & \begin{tabular}{|l} 
S.1.2 \\
$(3,5)$ \\
\end{tabular} & & & & \\
\hline & $\begin{array}{l}\text { S.2.1 } \\
(3)\end{array}$ & $\begin{array}{l}\text { S.2.2 } \\
(7,9)\end{array}$ & \begin{tabular}{|l} 
S.2.3 \\
$(3,7)$ \\
\end{tabular} & $\begin{array}{l}\text { S.2.4 } \\
(3,5,7)\end{array}$ & $\begin{array}{l}\text { S.2.5 } \\
(3)\end{array}$ & $\begin{array}{l}\text { S.2.6 } \\
(1,2,5)\end{array}$ \\
\hline & $\begin{array}{l}\text { S.3.1 } \\
(1)\end{array}$ & & & $\begin{array}{l}\text { S.4.1 } \\
(1,5)\end{array}$ & $\begin{array}{l}\text { S. } 4.2 \\
\text { (2) }\end{array}$ & $\begin{array}{l}\text { S. } 4.3 \\
(5)\end{array}$ \\
\hline Přehnutý & $\begin{array}{l}\text { P.1.1 } \\
(1,5) \\
\end{array}$ & \begin{tabular}{|l|} 
P.1.2 \\
$(1)$
\end{tabular} & & $\begin{array}{l}\text { P.2.1 } \\
(7)\end{array}$ & & $\begin{array}{l}\text { P.3.1 } \\
(3,4,7)\end{array}$ \\
\hline $\begin{array}{l}\text { Vodorovně } \\
\text { vyložený }\end{array}$ & $\begin{array}{l}\text { VV.1.1 } \\
\text { (2) }\end{array}$ & \begin{tabular}{|l} 
VV.1. \\
$(3)$ \\
\end{tabular} & & & & \\
\hline Ovalený & $\begin{array}{l}\text { O.1.1 } \\
(3,4) \\
\end{array}$ & $\begin{array}{l}0.1 .2 \\
(3,7) \\
\end{array}$ & & $\begin{array}{l}0.2 .1 \\
(8,9) \\
\end{array}$ & $\begin{array}{l}0.2 .2 \\
(2,3,5)\end{array}$ & \\
\hline & & & & & & \\
\hline
\end{tabular}




\begin{tabular}{|c|c|c|c|c|c|c|}
\hline \multicolumn{7}{|c|}{ Vzhůru vytažené okraje a okruží hrnců, jejich podtypy a varianty } \\
\hline $\begin{array}{l}\text { Vzhůru } \\
\text { vytažený }\end{array}$ & $\begin{array}{l}\text { V.1.1 } \\
(3-5,7)\end{array}$ & \begin{tabular}{|l} 
V.1.2 \\
$(1,3,4,7)$ \\
\end{tabular} & \begin{tabular}{|l} 
V.1.3 \\
$(3,5)$ \\
\end{tabular} & $\begin{array}{l}\text { V.2.1 } \\
(1-5,7) \\
\end{array}$ & $\begin{array}{l}\text { V.2.2 } \\
\text { (3) }\end{array}$ & $\begin{array}{l}\text { V.2.3 } \\
(1) \\
\end{array}$ \\
\hline $\begin{array}{l}\text { Vytažený } \\
\text { nízký }\end{array}$ & $\begin{array}{l}\text { VN.1.1 } \\
(1-3,5,7)\end{array}$ & $\begin{array}{l}\text { VN.1.2 } \\
(2,3,7)\end{array}$ & & $\begin{array}{l}\text { VN.3.1 } \\
(5)\end{array}$ & $\begin{array}{l}\text { VN.3.2 } \\
\text { (3) }\end{array}$ & \\
\hline & $\begin{array}{l}\text { VN.2.1 } \\
(1,5,7)\end{array}$ & $\begin{array}{l}\text { VN.2.2 } \\
\text { (1) }\end{array}$ & $\begin{array}{l}\text { VN.2.3 } \\
(3,4)\end{array}$ & $\begin{array}{l}\text { VN.2.4 } \\
\text { (3) }\end{array}$ & & \\
\hline $\begin{array}{l}\text { Vytažený } \\
\text { zužující se }\end{array}$ & $\begin{array}{l}\text { VZ.1.1 } \\
(1,3)\end{array}$ & \begin{tabular}{|l} 
VZ.1.2 \\
$(1,4)$
\end{tabular} & & \begin{tabular}{|l|} 
VZ.2.1 \\
$(1,3)$ \\
\end{tabular} & $\begin{array}{l}\text { VZ.2.2 } \\
(1,3,5,7)\end{array}$ & \\
\hline $\begin{array}{l}\text { Ploché } \\
\text { okruží }\end{array}$ & $\begin{array}{l}\text { OP.1.1 } \\
\text { (3) }\end{array}$ & $\begin{array}{l}\text { OP.1.2 } \\
\text { (3) }\end{array}$ & & \begin{tabular}{|l} 
OP. 2.1 \\
$(1,2,3,7)$
\end{tabular} & $\begin{array}{l}\text { OP. } 2.2 \\
\text { (2) }\end{array}$ & \\
\hline & & & & & & \\
\hline
\end{tabular}


Kateřina Těsnohlídková - Jakub Těsnohlídek - Petr Duffek:

Archeologie nejstaršího horizontu města Počátky (okres Pelhřimov)

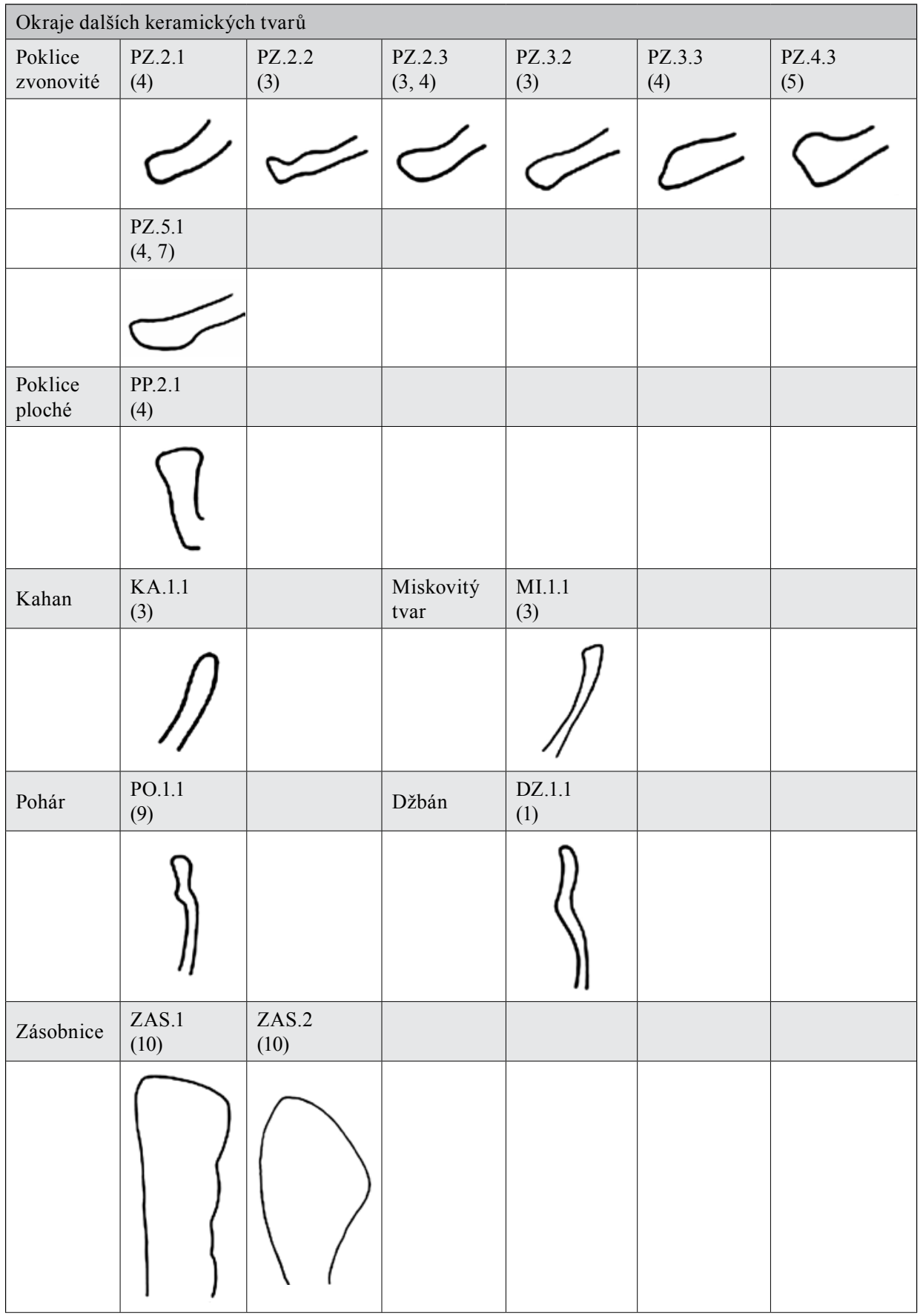

Příloha 2. Typáŕ okrajů hrnců a dalších keramických tvarů ze suterénu č. 0518. Za typem, podtypem a variantou okraje uvedena v závorce čísla $K T$, u kterých se daná varianta okraje vyskytovala.

Anhang 2. Aufstellung der Topfrandtypen und weiterer Keramikformen aus dem Souterrain Nr. 0518. Hinter dem Typ, Untertyp und der Variante der Ränder werden in Klammern die Keramikklassen angegeben, in denen die betreffende Variante vorkam.

142 


\begin{tabular}{|c|c|c|c|c|c|}
\hline R.01 & rýhy (do 1 mm) & & R.04 & $\begin{array}{l}\text { jednoduché vlnice } \\
\text { (nad } 2 \mathrm{~mm})\end{array}$ & \\
\hline $\begin{array}{l}\text { R.01.00 } \\
(1-3)\end{array}$ & neurčitelný počet & & $\begin{array}{l}\text { R.04.05 } \\
(3,7)\end{array}$ & $\begin{array}{l}\text { vysoké vlnice nad } \\
\text { sebou }\end{array}$ & \\
\hline $\begin{array}{l}\text { R.01.01 } \\
(1,3)\end{array}$ & 1 rýha & & R.05 & $\begin{array}{l}\text { hřebenová vlnice } \\
\text { (do } 2 \mathrm{~mm} \text { ) }\end{array}$ & \\
\hline $\begin{array}{l}\text { R. } 01.02 \\
(1-3,7)\end{array}$ & 2 a více rýh & & $\begin{array}{l}\text { R.05.01 } \\
\quad(7)\end{array}$ & 1 r̆ada & \\
\hline $\begin{array}{l}\text { R.01.04 } \\
(3,5)\end{array}$ & svazky rýh & & R.07 & $\begin{array}{l}\text { kombinace vlnic } \\
\text { a rýh/žlábků }\end{array}$ & \\
\hline $\begin{array}{l}\text { R.01.08 } \\
(2,7)\end{array}$ & $\begin{array}{l}\text { rýhy v nepravidel- } \\
\text { ném odstupu }\end{array}$ & & $\begin{array}{l}\text { R.07.00 } \\
(1,3,7)\end{array}$ & $\begin{array}{l}\text { neurčitelný počet, } \\
\text { postavení }\end{array}$ & \\
\hline $\begin{array}{l}\text { R.01.09 } \\
(1,3)\end{array}$ & rýhy řídce & & $\begin{array}{c}\text { R.07.01 } \\
(3,7)\end{array}$ & $\begin{array}{l}\text { rýha/žlábek a pod ním } \\
\text { vlnice }\end{array}$ & \\
\hline R.02 & $\begin{array}{l}\text { žlábky (nad } 2 \text { mm, } \\
\text { vodorovně) }\end{array}$ & & $\begin{array}{l}\text { R.07.02 } \\
\text { (3) }\end{array}$ & $\begin{array}{l}\text { rýhy/žlábky a pod } \\
\text { nimi } 1 \text { vlnice }\end{array}$ & \\
\hline $\begin{array}{l}\text { R. } 02.00 \\
(3-5,7, \\
10)\end{array}$ & neurčitelný počet & & $\begin{array}{l}\text { R. } 07.03 \\
(1,3,5)\end{array}$ & $\begin{array}{l}1 \text { vlnice a pod ní } \\
\text { rýhy/žlábky }\end{array}$ & \\
\hline $\begin{array}{c}\text { R.02.02 } \\
(1,3,5,10)\end{array}$ & 2 a více žlábků & & $\begin{array}{c}\text { R.07.04 } \\
(1,3)\end{array}$ & $\begin{array}{l}\text { rýha/žlábek, několik } \\
\text { vlnic, rýha/žlábek }\end{array}$ & \\
\hline $\begin{array}{c}\text { R.02.03 } \\
(3,7)\end{array}$ & husté žlábky & & $\begin{array}{c}\text { R.07.05 } \\
(4,7)\end{array}$ & $\begin{array}{l}\text { vlnice mezi } 2 \text { rýhami/ } \\
\text { žlábky }\end{array}$ & \\
\hline $\begin{array}{l}\text { R. } 02.08 \\
(5,7)\end{array}$ & $\begin{array}{l}\text { žlábky v nepravi- } \\
\text { delném odstupu }\end{array}$ & & $\begin{array}{l}\text { R.07.06 } \\
\text { (10) }\end{array}$ & $\begin{array}{l}\text { rýha/žlábek mezi } \\
2 \text { vlnicemi }\end{array}$ & \\
\hline $\begin{array}{l}\text { R.02.09 } \\
\text { (1) }\end{array}$ & žlábky řídce & & $\begin{array}{l}\text { R. } 07.07 \\
\text { (3) }\end{array}$ & $\begin{array}{l}\text { stř́ídání: rýha/žlábek, } \\
\text { vlnice, rýha/žlábek, } \\
\text { vlnice, rýha/žlábek }\end{array}$ & \\
\hline R.03 & $\begin{array}{l}\text { jednoduché vlnice } \\
\text { (do } 2 \mathrm{~mm} \text { ) }\end{array}$ & & & & \\
\hline $\begin{array}{l}\text { R.03.00 } \\
\quad(1)\end{array}$ & neurčitelný počet & & V.03 & obloukovité vrypy & \\
\hline $\begin{array}{c}\text { R.03.01 } \\
(1,3,5,7)\end{array}$ & 1 nízká vlnice & & $\begin{array}{l}\text { V.03.00 } \\
(10)\end{array}$ & jednotlivě & \\
\hline $\begin{array}{c}\text { R.03.02 } \\
(1,3,5,7)\end{array}$ & 1 vysoká vlnice & & $\begin{array}{l}\text { V.03.01 } \\
(5)\end{array}$ & vodorovná linie & \\
\hline
\end{tabular}

Příloha 3. Typář výzdoby vyskytující se na keramice ze suterénu č. 0518. Za typem výzdoby uvedena v závorce čísla KT, u kterých se daná výzdoba vyskytovala. Upraveno podle Procházka 2007, 265-267.

Anhang 3. Aufstellung der Verzierungstypen, die auf der Keramik aus dem Souterrain Nr. 0518 vorkommen. Hinter dem Verzierungstyp werden in Klammern die Keramikklassen angegeben, in denen die betreffende Verzierung vorkam. Bearbeitet nach Procházka 2007, 265-267. 
